NBER WORKING PAPER SERIES

\title{
WHAT WE SPEND AND WHAT WE GET: PUBLIC AND PRIVATE PROVISION OF CRIME PREVENTION AND CRIMINAL JUSTICE
}

\author{
Ann Dryden Witte \\ Robert Witt \\ Working Paper 8204 \\ http://www.nber.org/papers/w8204 \\ NATIONAL BUREAU OF ECONOMIC RESEARCH \\ 1050 Massachusetts Avenue \\ Cambridge, MA 02138 \\ April 2001
}

The authors are grateful to Roy Carr-Hill and seminar participants at the Institute for Fiscal Studies, University of London for useful discussions and comments. The views expressed herein are those of the authors and not necessarily those of the National Bureau of Economic Research.

(C) 2001 by Ann Dryden Witte and Robert Witt. All rights reserved. Short sections of text, not to exceed two paragraphs, may be quoted without explicit permission provided that full credit, including $\odot$ notice, is given to the source. 
What We Spend and What We Get: Public and Private Provision of Crime Prevention and Criminal Justice Ann Dryden Witte and Robert Witt NBER Working Paper No. 8204

April 2001

JEL No. H5, K14, K42

\section{ABSTRACT}

In this paper, we consider a number of issues regarding crime prevention and criminal justice. We begin by considering how crime is measured and present both general and specific evidence on the level of crime in a variety of countries. Crime is pervasive and varies substantially across countries. We outline the arguments for some public roll in crime prevention, enforcement, prosecution, defence, and adjudication. We consider the relative role of the public and private sectors in crime control and criminal justice. We discuss various measures for the effectiveness of the criminal justice system. We conclude by suggesting some potential areas for research.

Ann Dryden Witte

Department of Economics

Wellesley College

Clapp Library 314

106 Central Street

Wellesley, MA 02481

and NBER

awitte@wellesley.edu
Robert Witt

Department of Economics

University of Surrey

Guildford, Surrey

GU2 5XH

United Kingdom

r.witt@surrey.ac.uk 


\section{INTRODUCTION}

Communities that cannot provide an acceptable level of security for persons and property will not long survive. Economists have long pointed out that even if such communities were to survive they would not prosper. Communities where the strong are allowed to freely victimize the weak will be small and surviving members will have to spend most of their resources on defense.

When property can be freely taken by theft and deception, no one has the incentive to invest. Protection of property from taking is the most basic of all property rights. Without this protection, the problem of the common is pervasive.

Adam Smith believed that the protection of person and property was the most important duty of government after national defense. Yet, somewhat surprisingly economists interested in public economics have rarely analyzed the nature of the government's roll in providing domestic security for citizens. A search of both general and advanced textbooks on public economics revealed no text that considered government expenditures and the government roll in crime prevention and criminal justice.

In this paper, we seek to use the perspective and tools of public economics to examine crime control and criminal justice. We begin by presenting both general and specific measures of the level and nature of crime for a variety of countries.

Unsurprisingly crime is pervasive. However, the level of crime varies substantially across countries. In the section that follows, we outline the arguments for at least some public provision of crime prevention, enforcement, prosecution and defense, and adjudication. We briefly consider sentencing. In Section 4, we describe the relative rolls of the private and public sectors in the provision of crime control and criminal justice. In the penultimate section, we summarize some research on the effectiveness of public expenditures on crime control and criminal justice. We conclude by suggesting some potentially productive research directions.

\section{WHAT IS THE PROBLEM?}


Crime is everywhere. Even though countries define crime differently in their criminal codes no country is without crime. Some things are crimes almost everywhere. These have come to be called the core or traditional crimes-murder, robbery, rape, theft, burglary, fraud and assault. Even for these crimes, measuring the extent of the activity is, to say the least, difficult. Perpetrators have strong incentives to keep their activities secret and discovery by public or private enforcement agencies is limited both by resources and evidence.

Crime is, of course, not limited to the traditional crimes. Trafficking in illegal or stolen property is widespread and increasingly transnational. Financial and environmental crimes, sometimes carried out by large multinational enterprises, can and often do cause mass human suffering and financial losses. One need only think of the Bhopal disaster or the BCCI scandal.

Obtaining an overall measure of the extent of crime that is comparable across countries is a daunting task. Fortunately, researchers at the World Bank have carefully compiled, analyzed and aggregated indicators for the "rule of law", graft and political instability and violence from 13 different sources for over 150 countries. See Kaufmann, Kraay and Zoido-Lobaton (1999a, 1999b) for a list of sources and methodology used. They provide an aggregate measure for each indicator that ranges from -2.5 to 2.5 . Countries with higher numbers are deemed to be more law abiding. Kaufmann, et al. provide standard errors as well as point estimates for each country.

Kaufmann's, et al. rule of law provides, as far as we are aware, the broadest (in terms both of types of crime and geography) indicator of crime that is available. To obtain a measure for the rule of law, Kaufmann, et al. aggregate a number of indicators that measure the extent to which agents have confidence in and abide by the rules of society. The indicators include perceptions of the incidence of both violent and nonviolent crime, the effectiveness and predictability of the judiciary and the enforceability of contracts. Kaufmann, et al. indicate that together these indicators measure the success of a society in developing an environment in which fair and predictable rules form the basis for economic and social interaction.

Figure 1 displays Kaufmann, et al. measures for the rule of law for selected countries. The diamond in the center of the country name is the point estimate. The lines 
emanating from the point estimates provide the $90 \%$ confidence interval for each estimate.

\section{Insert Figure 1 here}

From these data it is clear that some countries (e.g., Switzerland, Singapore) have much stronger rules of law than other countries (e.g., the Congo, Iraq). It is also clear that the range of reasonable estimates for the middle range countries (e.g., Brazil, India, Turkey) do not differ significantly. Still, these estimates provide a useful broad assessment of the extent of the crime problem across countries.

Kaufmann 's, et al. indicator for graft is designed to measure perceptions of corruption, an important aspect of crime (see Figure 2). Kaufmann, et al. describe this measure as indicating the degree to which public power is used for private gain. This measure of crime is narrower than the rule of law considered previously, but still it provides a valuable measure of the extent of an important and often overlooked aspect of crime. Rankings are generally similar, but not identical to those for the rule of law. For example, Italy is quite like Spain in terms of the rule of law, but has a much lower rating than Spain for graft. Tunisia is quite like Brazil in terms of graft, but Tunisia has a higher measure for the rule of law than does Brazil.

\section{Insert Figure 2 here}

While graft measure public property offences, Kaufmann's, et al. political instability and violence might be considered a measure of the likelihood of violent crime related to government. Figure 3 present measures public perceptions regarding the likelihood that the government in power will be destabilized or overthrown by unconstitutional or violent means. On this indicator Italy ranks above Spain and Algeria joins the Congo and Iraq at the bottom of the scale.

\section{Insert Figure 3 here}

Turning from general measures of lawfulness to measures for the core crimes, one finds less information both in terms of the number of countries for which comparable data are available and the crimes for which the extent is measured. Before proceeding, it is important to note that reports of crime to the police, the most broadly cited statistics in many countries, are generally more a measure of the functioning of the criminal justice system than of crime (Newman, 1999). 
That being said some crimes are more difficult to hide than others. For example, murder is generally known because a dead body rarely remains successfully hidden for long. In stable countries, the number of murders (homicides) is generally quite well recorded by the police. ${ }^{1}$ Further vital statistics provide a check on the number of homicides in countries with well-functioning public health departments.

The United Nations Crime and Justice Survey (UNCJS), the International Police Organization (INTERPOL) and the World Health Organization (WHO) provide independent estimates of the extent of homicide for a variety of countries. WHO reports only on successful, completed acts of homicide from vital statistics. UNCJS and INTERPOL rely either directly or indirectly on the reports of national criminal justice systems.

As can be seen in Figure 4, the three sources of data generally agree rather closely on the homicide rate for most countries. However, there are notable exceptions. For example, the different sources provide quite different estimates for Bulgaria and the Russian Federation. While the sources of data indicate quite different magnitudes for these countries, all sources indicate that these countries have higher murder rates than other countries for which data were available. For other countries, homicide rates range from under 1 per 100,000 (i.e., Japan and Norway) to over 2 per 100,000 (e.g., Finland and Israel).

\footnotetext{
${ }^{1}$ Newman (1999), p. 11.

${ }^{2}$ Raw data on homicide from the UNCJS and INTERPOL include attempts as well as completed murders. We use figures given in the notes to Box 0.7 of Newman 1999.
} 
Figure 4

Homicide Rates per 100,000 Population in 1993

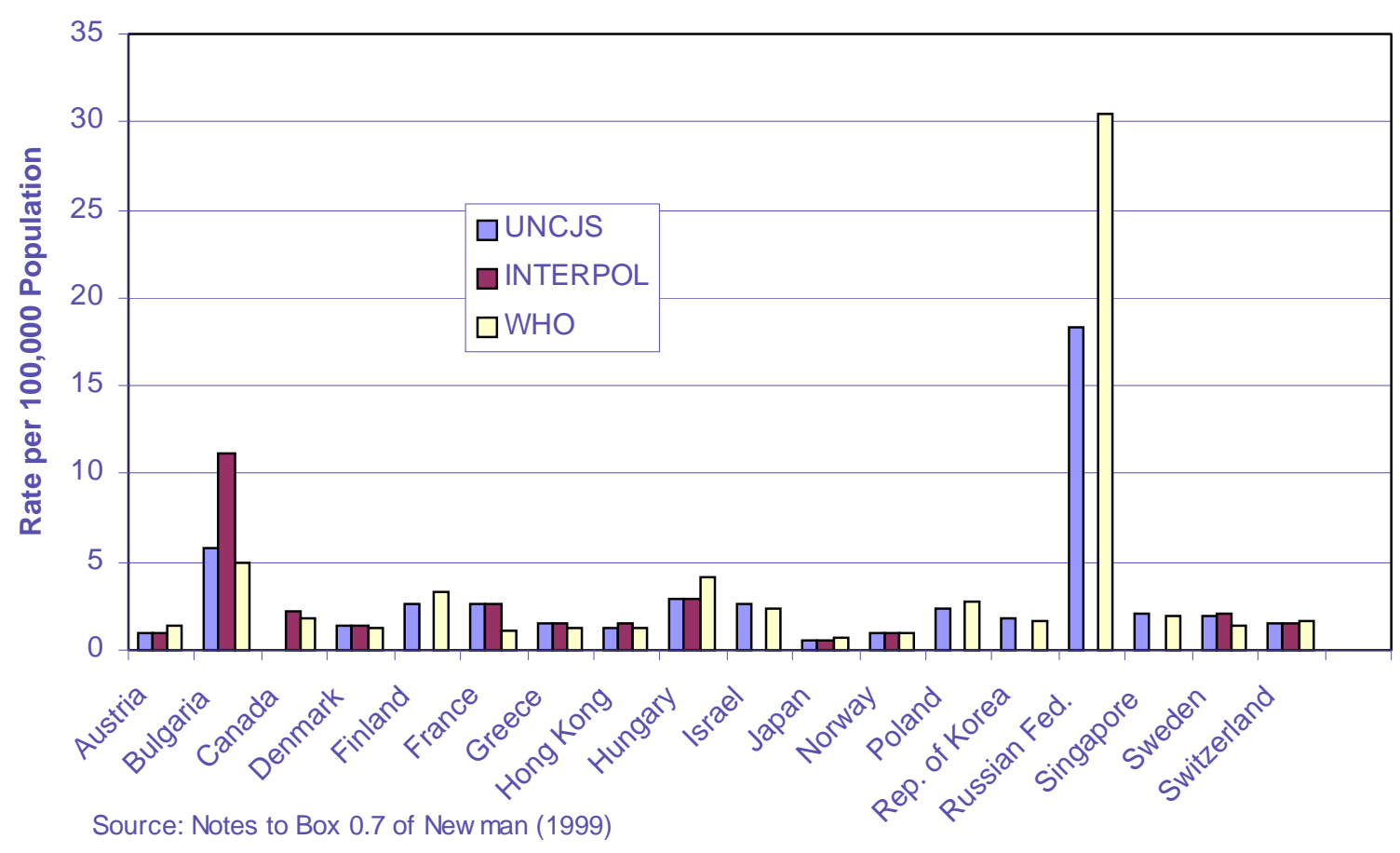

For crimes other than murder measurement is more difficult. Surveys of victims provide reasonably accurate measures of offenses for which there is an identifiable victim that knows that he/she has been victimized and is willing to report it in a survey setting. For international comparisons, the International Crime Victim Surveys (ICVS) that were carried out in 1989, 1992/1994 and 1996 provide results for a number of industrialized, transition and developing countries. ${ }^{\text {B }}$ These surveys use consistent definitions of offenses while official statistics depend on the definition of offenses in the criminal law, which can vary widely from country to country. The surveys asked about the following offenses: (1) contact crimes (robbery, sexual offences, threats and assaults), (2) burglary (including attempts), (3) car crimes (car theft, theft from car and car damage) and (4) other thefts (motorcycle theft, bicycle theft and other personal theft).

These surveys reveal that more than half of urban residents report having been a victim of one or more of the covered offenses during the last five years. Being the victim of a crime is a common occurrence in all urban areas. Rates of victimization are highest

\footnotetext{
${ }^{3}$ For a description of methodologies and countries included, see Note 3 to Box 0.9 of Newman (1999).
} 
in Africa and Latin American where almost $3 / 4$ of urban residents report having been victimized during the last five years. Rates are lowest in Asia where $45 \%$ of urban residents report victimization over a five-year period. Victimization rates in the US, England and Wales, and West Germany are quite similar with between $60 \%$ and $65 \%$ of urban residents reporting victimization during a five-year period.

The ICVS asked respondents about their perception of the relative seriousness of various types of crimes. Western European and North American countries tended to rank violent crimes (e.g., robbery with a weapon) most seriously while African, Asian, Central and Eastern European, and Latin American countries ranked car theft as the most serious of the offense considered.

Urban residents have over a 50\% chance of being the victim of a contact crime during a five year period in Columbia and less than a $10 \%$ chance of being the victim of a contact crime in Switzerland. In Western Europe, the Netherlands reports the highest level of victimization for contact crimes (22\% of urban residents report victimizations). This reported rate of victimization is approximately the same as Russia's. In the US, approximately $20 \%$ of urban residents report that they have been victims of contact crimes during a five-year period.

Car theft is most frequently reported in New Zealand (just under 50\% of urban residents report car thefts during a five year period) and least frequently reported in China (less than $2 \%$ of the Chinese report car thefts during a five year period). These numbers point up the importance of opportunity. For most property crimes, victimization rates are higher in wealthier countries where there is more of value to steal. Theft is significantly correlated with holdings of durable goods.

It is more difficult to gage the extent of crimes other than murder and those covered by the ICVS. Official records of crime such at the US Federal Bureau of Investigations (FBI) Uniform Crime Reports (UCR) reflect many things in addition to the underlying crime rate (e.g., the willingness of residents to report crimes to the police, the reporting practices of police agencies). We discuss a few attempts (mainly cross national) to study other types of offending here.

The ICVS like most victimization surveys is concerned with offense where individuals or households are the victims. A few victimization surveys have also sought 
to discern the extent to which businesses are victimized. For example, a 1993 survey of commercial establishments in England and Wales reports that 8 out of 10 retailers and 2 out of 3 of manufacturers experience one or more crimes covered by the survey in 1993. Commercial victimization appears to be highly concentrated with $3 \%$ of retailers experiencing $59 \%$ of the crime reported in the survey. The reported risk of victimization and the amount of the loss was higher for retailers and manufacturers than for households (Mirrlees-Black and Ross, 1995a, 1995b).

As is well known, the core crimes with the exception of fraud is like basketball primarily a young man's game. In a very interesting study, Junger-Tas, Gert-Jan and Klein (1994) report the results of surveys of young people (14-21) in 12 countries that were carried out in 1992. As can be seen in Figure 5, rates of self-reported offending vary substantially across the areas studied. For example, young people in Athens report the highest rates of violent crime with more than half of the respondents reporting that they had committed an offense during the last year. Young people in Helsinki report the highest rates of property crime (just under 50\%) and young people in England and Wales the highest rate of drug offending (26\%). 


\section{Figure 5}

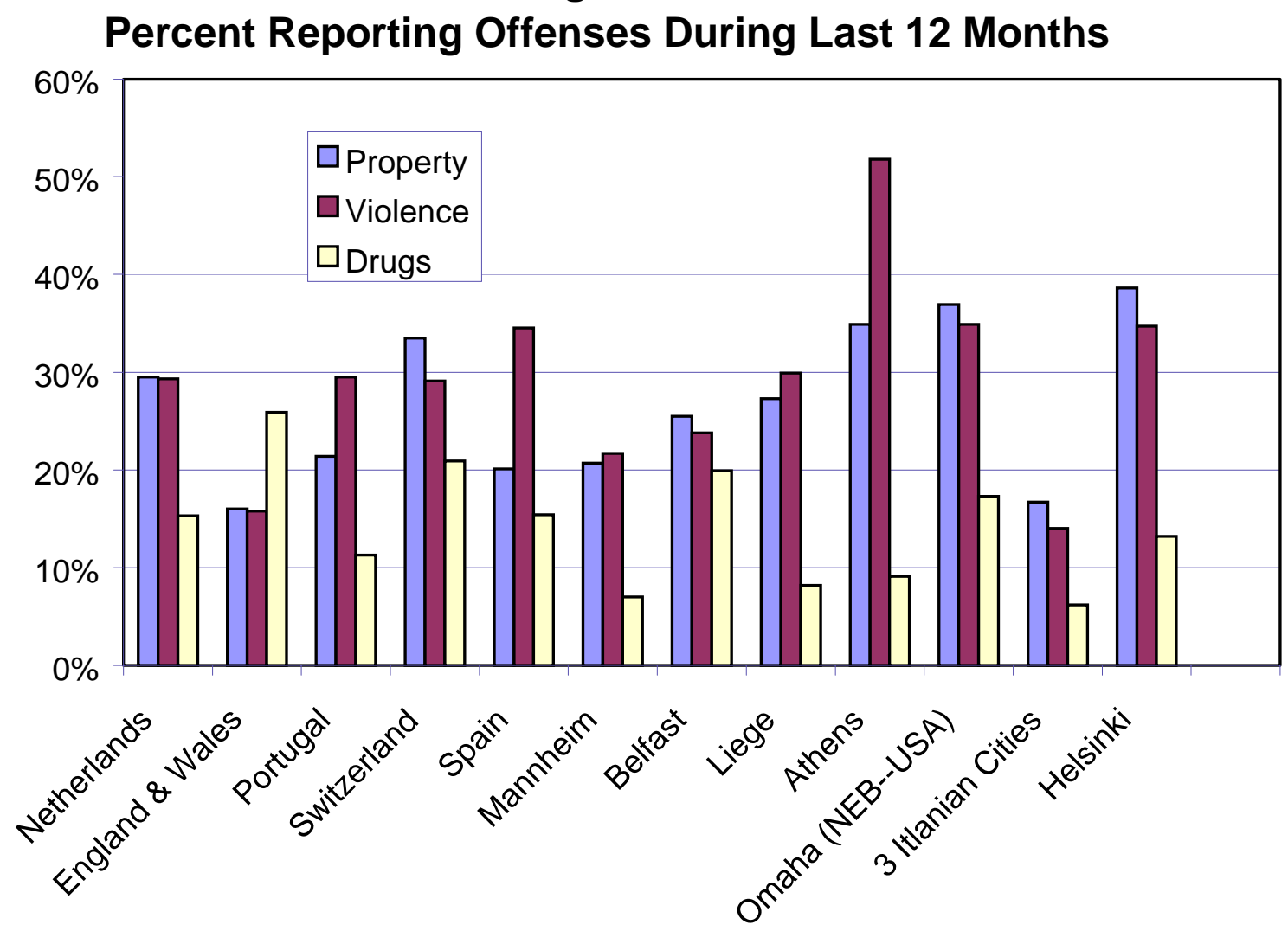

Source: Box 0.10 of Newman (1999)

Regardless of whether one considers general measures of law abidingness, victimization reports or self reports of crime by the young, the message is the same--there is a lot of crime. That being the case we turn to the next issue. What, if anything should the public sector do about it?

\section{WHAT PUBIC ROLL?}

As H.L.A. Hart has noted, communities must have restrictions on the free use of violence, theft and deception if they are to survive and prosper (Hart, 1994, p. 91). To put it somewhat differently, societies will place restrictions on the core or traditional crimes, murder, rape, robbery, theft, burglary, fraud and assault.

The question is how these restrictions will be imposed. In what Hart calls primitive societies, these restrictions may be imposed by custom and informal means of 
social control. However, as communities grow, develop and become more heterogeneous, restrictions against committing the core crimes tend to become a matter of religious or governmental rules or a mixture of both.

Today, the legal systems that outlaw the core crimes can be classified broadly into three types: (1) civil law, (2) common law and (3) Islamic Law (Newman, 1999). Only in Islamic law do we find a mixture of religious and governmental restrictions against the core crimes. Islamic law tends to encourage non-governmental response to the core crimes, including murder (Groves, Newman and Corrado, 1987). Islamic law tempers retaliation by encouraging forgiveness. Under Islamic law, a victim or a victim's family may waive retaliation and receive instead a money payment from the perpetrator of the crime. In such a situation the government will not become involved with either the offender or the offense. Only if the perpetrator and victim cannot agree does the government become involved.

In both the common law and civil law traditions, it is the government who forbids the core crimes. The civil law tradition originated as a combination of Roman Law and papal statements of the Roman Catholic church. However, most countries that follow the civil law tradition today (e.g., France, Germany, Brazil, Russia, Indonesia) rely on secular legislation as the source of restrictions against the core crimes. Under a civil law system, there is a sharp separation of powers. Legislatures make the law and judges apply

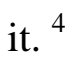

By way of contrast, the common law tradition relies on the customs of the people as its original source. Much of common law became codified over time. For example, restrictions against the core crimes are now generally legislated. However, judges may and do interpret the legislated law in particular cases. The judge has the ability to make laws in the common law tradition, but not in the civil law tradition. Countries that use the common law tradition include England, India and the United States.

Why do most developed countries empower one or more arms of government to determine what is criminal? The rise of the power of government to determine what is a crime coincides with the rise of the nation state, industrialization and urbanization. The rulers of the new nation states sought to monopolize control over the use of force in the

\footnotetext{
${ }^{4}$ In developed countries the Civil Law and Common Law traditions have become more similar during the post World War II period.
} 
hands of their servants for quite obvious reasons. Industrialization and urbanization weakened the force of traditional or customary law. The rise of secular society weakened religious restrictions against the core crimes although religious restriction can still be very important in preventing crime.

Standardization and codification of criminal laws lowered the transaction costs required for both inter-personal interaction and property transfers. Reliable and standardized rules allowed for greater economies of scale by lowering the costs of trade and travel over larger areas. As noted earlier, protection of property from taking by theft or fraud is the most basic of all property rights and necessary to prevent the problem of the commons. The newly emergent nation state was in a unique position to undertake the codification and had the incentive to do so to solidify its power.

Many believe that crime is very distinct from other types of illegal acts because crimes are believed not only to harm the victim, but also to harms other member of society. Crimes, particularly the core crimes, are believed to be offenses against society not merely offenses against the individual (Kaplan, et al., 1991; Cooter and Ulen, 2000). In economic terms, crime produces negative externalities and will be too high if there is no public intervention.

An additional distinguishing feature of crimes as opposed to most civil offenses, such as torts, is that conviction of a crime requires a finding of mens rea (a guilty mind). If enforcement costs were zero, we might want to eliminate the core crimes. By way of contrast, we only wish to encourage and efficient level of prevention expenditures in the case of torts. The intent to do physical harm or to transfer property by force or deception requires stronger deterrence than do accidental occurrence and may even justify putting the offender in a position where he can no longer offend (i.e., incapacitating the offender).

Some have argued that many crimes should be handled like torts with the victim bringing a case for compensation (e.g., Friedman, 2000). Others argue that crimes are very different from torts. For some crimes (e.g., rape, robbery), some argue that no amount of compensation can make the victim whole (Cooter and Ulen, 2000). Others argue that the intent required for a crime requires punishment/retaliation (United States v. Bergman, 1976). 
Regardless of the position one takes in these arguments, even the most ardent proponents of treating many things that are currently crimes as torts find a need to criminalize in some circumstances. For example, Friedman suggests that criminalization is necessary for acts in which the victims are anonymous (e.g., highway robbery) or defendants are "judgment proof" (too poor to pay compensation to victims). The matter in dispute is what acts should be criminal.

\section{Police}

Police do many things, but we are concerned only with their crime control functions. These functions include crime prevention and the apprehension of offenders. (a) Preventing Crime

What is the proper roll of government in preventing crime? As we will show later, crime prevention is now generally split between the private and public sectors with the private sector generally spending more on prevention than the public sector.

Much crime prevention does not involve the use of force and, hence, the argument for public provision is greatly weakened. When crime prevention does require the use of force, the case for public provision is stronger (Hart, et al., 1997). Public monopoly of and control over the legitimate use of force is central to the provision of standard levels of security for person and property. Further, to be effective the police require the sympathy and cooperation of the public. Public police may be better able to nurture these needed characteristics.

Public police forces are relatively new and emerged along with large, heterogeneous urban areas. They arose in response to a public outcry for more order. The first public police force was established in London in 1829 to provide a full-time day and night patrol to prevent crime. Sir Robert Peel who was mainly responsible of establishing the force under the Metropolitan Police Act insisted that political patronage be excluded from appointments and promotions (Miller, 1977 as excepted in Kaplan, et al., 1991). Boston established a public police force in 1837 to prevent violence between Protestants and Catholics. New York City's Municipal Police Act established a semi-military day and night patrol force in 1845. The New York force was not insulated from political patronage (Kaplan, et al. pp. 141-145).

(b) Apprehension of offenders 
Police are not only asked to prevent crime, but also to apprehend offenders when crime does occur. Apprehension often requires the use of force and, hence, a reasonably good case can be made for public provision (Hart, et al., 1997). Also, in contrast with many civil offenses such as automobile accidents, the identity of the perpetrator may be unknown to the victim (Polinsky and Shavell, 1999). Even if the perpetrator's identity is known the victim may well not be willing to press a case.

As noted earlier, crime can produce very high negative externalities (e.g., fear of going out when someone has recently been murdered in the neighborhood) and so both prevention of crime and apprehension of criminals will be inadequately supplied by the private sector. The distribution of prevention and apprehension is also likely to be much higher in wealthier than in poorer neighborhoods if these activities are financed by the private sector.

To summarize, both efficiency and equity arguments call for public financing of at least a minimal level of police services in larger communities. The wealthy will often choose to purchase additional prevention to protect both their person and their property.

The fact that the police's crime fighting activities can involve the use of force in a wide array of situations suggests that public provision rather than contracting with the private sector will likely be best for these activities (Hart, et al., 1997). Other police functions (e.g., record keeping) may well be better contracted out than provided by the public sector.

\section{Prosecution}

The roll of the state in persecuting crime clearly depends upon whether or not crime is seen mainly as an offense against the state or as an offense against the victim. Countries as diverse as China, France and the USA see crime mainly as an offense against the state or the community as a whole and public officials generally prosecute criminal cases. However, the powers and type of official empowered to prosecute crimes varies substantially across countries. In Continental Europe, the prosecutor is an appointed career civil servant of the central government with a close relationship to the court. Most prosecutors in the United States are locally elected officials with substantial autonomy from both the judicial and executive branches of government (Kaplan, et al., 1991, 289-291). 
In China, private citizens (generally the victim or the victim's relatives) prosecute less serious crimes while the state prosecutes more serious offenses (Newman, 1999, p. 40). From an economic point of view, this split can be justified because of the larger negative externalities arising from more serious crimes.

Traditional English common law sees crime as an offense against the victim not as an offense against some broader community. It was not until 1879 that England created an Office of Public Prosecutions. The Director of this Office is a career civil servant. The actual trial of cases is assigned to barristers in private practice designated as Crown Counsel. For a discussion see Newman (1999, p. 132) or Kaplan, et al. (1991, pp. 287-306).

One can easily argue for public expenditures to secure prosecution of crimes that cause large negative externalities since private parties would be expected to bring too few suits. Arguments for public provision of prosecution generally rest on the need to maintain a high level of standards in the prosecution of serious criminal cases. As Kaplan, et al. express it: "The prosecutor is also a representative of the government upon whom the courts, and society, impose a standard of ethics which may transcend any particular rule" (1991, p.311). Contracts for prosecutors would tend to be quite incomplete. Privately contracted prosecutors would have strong incentives to lower standards in order to lower costs (Hart, et al, 1997).

\section{Defense}

Most developed countries whether following a civil or common law legal tradition provide public funding to allow indigent defendants to hire legal counsel in serious criminal cases. The need for representation is probably stronger under the adversarial common law tradition where the judge can only consider the evidence brought before her than under the inquisitional civil tradition where the judge can actively search for information.

Economic argument for the provision of defense counsel for the indigent rest mainly on equity grounds although it would be possible to argue that it is inefficient to imprison the innocent poor. Horizontal equity dictates that the equally situated should be treated equally. In terms of the core crimes, equal situation might well be defined as being equally innocent or equally guilty. Defendants without legal counsel will clearly 
not be in a situation that is equivalent to the situation of those who are able to purchase competent legal counsel.

The USA has a large, complicated and much criticized "system" for providing defense counsel for the indigent. The sixth amendment to the US Constitution establishes the right to counsel in Federal criminal prosecution. However, most of the core crimes are prosecuted at the local level not at the Federal level. During the 1960s and 1970s, a series of US Supreme Court cases (e.g., Gideon v. Wainwright, 1963, Argersinger v. Hamilin, 1972) established indigents' right to counsel for all criminal prosecutions that carry a sentence of imprisonment.

The Supreme Court did not indicate how state and local government were to provide indigent defense counsel or what source of funds would be used to pay for indigent defense. Currently, local governments (e.g., the Counties) are primarily responsible for providing defense counsel for the indigent. The majority of funding for indigent defense comes from local government although the state share of funding has grown over the years (Smith and DeFrancis, 1996).

The system for providing indigent defense in the US varies markedly from place to place. However, three basic methods are used:

- Assigned counsel programs appoint indigent counsel on a case-by-case basis. The counselor is chosen from members of the local, private bar.

- Under contract attorney programs, the local or state government contracts with individual private attorneys, private law firms or local bar associations to provide indigent defense.

- Under public defender programs, salaried staff of fill-time or part-time attorneys provide indigent defense. The public defenders may be employed by state or local government or by non-profit corporation contracted to provide indigent defense (Kaplan, et al, 1991, p. 351).

About three-fourths of inmates in State prisons and about half of those in Federal prison in the US received publicly provided legal counsel for the offense for which they were serving time (Smith and DeFrancis, 1996). The quality of publicly provided legal counsel varies widely both across the US States and, in many states, across local 
jurisdictions. In 1986, the cost per case of providing defense counsel ranged from a low of $\$ 63$ in Arkansas to a high of $\$ 540$ in New Jersey (Kaplan, et al., 1991, p. 353).

Horizontal equity is not achieved by the current US system for indigent defense. Further, as noted by Posner, criminal defendants have less access to the private market for lawyers than do defendants in civil cases where damage awards are possible (Merritt v. Faulkner, 1983).

\section{Adjudication}

The need for impartial adjudication of guilt in criminal cases is widely accepted. In traditional societies, this adjudication was often by a body of chiefs or elders. In the course of economic development and urbanization, criminal law and criminal procedure became increasing complex and a widely respected, informal body to adjudicate more difficult to construct and use. The increasing complexity and impersonality of adjudication has led to the increasing use of trained personnel to referee the trial/inquisition (e.g., enforce criminal procedure) and establish matters of law. Still, adjudication is in many countries a task that is carried out jointly by lay citizens and trained personnel.

For example, in the US, a jury of peers (selected from voter registration lists or other compilations of residents) determines the facts and the quilt or innocence of the accused. The judge referees the proceedings (e.g., enforces proper procedure and the admission of evidence), instructs the jury, determines matters of law and decides on the sentence a convicted defendant will receive after found guilty. ${ }^{\text {In }}$ the US judges, may be elected or appointed and the judiciary is separated from the executive or legislative branch of governments.

In Germany, lay judges often sit with professional judges in criminal trials (Aronowitz, 2000). By way of contrast, in Japan, the jury system has by and large been suspended and judges chosen on the basis of national level examinations adjudicate in criminal trials (Moriyama, 2000).

As noted by Judge Richard Posner, impartial adjudication is central to well functioning judicial system. As Posner put it: "the rules of the judicial process have been designed both to prevent the judge from receiving a monetary payoff from deciding a

\footnotetext{
${ }^{5}$ When criminal sentences were largely indeterminate (e.g. 5 years to life), judges and parole boards had substantial discretion. The move to determinate sentencing (e.g., sentencing guidelines) decreased the amount of sentencing discretion available to judges.
} 
case in a particular way and to minimize the influence of politically effective interest groups on his decisions Posner, 1992, p.534). Posner's first requirement suggests that forprofit provision of adjudication is a non-starter. His second requirement suggests that some insulation from electoral politics may be desirable.

But why do so many adjudication system involve, the lay public? One possible justification for lay involvement in adjudication may be to obtain both public support for and tempering of legal outcomes in the criminal arena. For example, it is well know that juries will often not convict when the potential penalty is not in accord with community feelings regarding what is appropriate.

\section{Punishment}

Punishments for criminal offense range widely: death (capital punishment); depravation of liberty (up to imprisonment for life); corporal punishment; control in freedom (e.g., probation and parole); fines; warnings or admonitions; and community service orders. According to the fifth United Nations Criminal Justice Survey (UNCJS), which obtained information on crime and criminal justice for 1993/1994 for a wide variety of countries, deprivation of liberty (i.e., imprisonment) was the most common form of criminal punishment with $35 \%$ of cases resulting in this type of sentence. Fines were the next most common sentence and were used in 33\% of the cases (Newman, 1999, pp. 89-90).

The relative use of fines and imprisonment varies widely across countries. For example according to the UNCJS survey, adjudicated criminal cases in Columbia always result in imprisonment, $96 \%$ of criminal cases resulted in imprisonment in Greece, 92\% in Mexico and $60 \%$ in Italy. By way of contract, in Japan, $95 \%$ of adjudicated cases resulted in fine, $82 \%$ in Myanmar, 79\% in England and Wales and 70\% in Egypt and Germany.

After carrying out a quantitative examination of sentencing practices, Shinkai and Zvekic conclude that the level of development of the country, economic situation, or region could not explain variations in sentencing practices. They conclude that crossnational variations in sentencing patterns are best explained by the "availability and acceptability of the sentencing options" (Newman, 1999, p. 91). 
Economists have been interested in optimal sentencing since the work of Becker (1968) and Stigler (1970). Economists generally conclude that fines should be preferred whenever they can be imposed. See for example, Posner (1992, p. 227). The argument for fines rests on their production of revenue for the state, victim or both and the high costs of imprisonment. The major economic arguments for the use of imprisonment for the core crimes rest on the fact that many who commit crimes are too poor to pay a fine that would provide optimal deterrence. For a discussion see Kaplow and Shavell (1999). This is so both because of their penury and because many of the core crimes have low probabilities of the offender being penalized and, hence, would require very high fines if optimal deterrence were to be achieved. For example, in New South Wales (Sydney, Australia and surrounding communities), crime statistics for 1996 indicate that as a whole those who break and enter buildings, steal cars, rob and assault others have only a $4 \%$ chance of being convicted and less than a $1 \%$ chance of going to prison. The reason for the low probability of apprehension and punishment for these crimes is mainly due to victims' failures to report the offenses to the police (54\% of the offenses are reported), failures of the police to record reported offenses ( $40 \%$ of crimes are recorded by the police) and failures of the police to find the perpetrator (7\% of the crimes are cleared by the police) (Newman, 1999, p.75).

Another economic argument for imprisonment rather than fines is that imprisonment quite successfully incapacitates offenders and fines do not. The social benefit of this incapacitation depends upon the extent to which offenders will continue to offend and on the elasticity of supply of offenders. This suggests that imprisonment of consistently violent offenders will have higher social benefits than will imprisonment of those who commit a "crime of passion." Certainly it argues against the tendency in the USA to use scare prison resources for drug dealers. As my son, who lives on the lower east side of New York, says: "Mom, they are like cockroaches—as soon as one leaves there is another to replace him." Society achieves little decrease in drug dealing by incarcerating drug dealers.

The arguments presented to this point suggest that wealthy offenders with little likelihood of offending again should be fined not imprisoned. While this is largely the 
case, it is not always so. Why? Before turning to possible economic arguments for imprisoning such offenders, we will consider the reasons judges provide.

In United States v. Bergman (1976), a 64-year-old rabbi with an excellent reputation for community service was convicted of fraudulently charging the government for services rendered by nursing homes that he owned. In sentencing Bergman to a short term of imprisonment, Judge Marvin Frankel carefully enunciated his reasoning. He concluded that both general deterrence and equal justice required a prison sentence in this case.

It is also interesting to consider Judge Kimba Wood's reasoning when sentencing the US junk bond inventor Michael Milken to prison. She found that a prison term was necessary in the Milken case to achieve general deterrence (i.e., the need to prevent others from violating the law). Her reasoning is interesting. She found that prison sentences are viewed as one of the most powerful deterrents to the financial community. She also reasoned that crimes, like security fraud, which are hard to detect require greater punishment in order to deter others from committing them (Kaplan, et. al., 1991, pp. 571$575)$.

In some ways, the arguments of Judge Frankel and Judge Wood are like those of economists, but in other ways they are quite different. Both Bergman and Milken were capable of paying large fines (indeed, Milken paid very large fines). Being barred for life from working in the security industry effectively incapacitated Milken and Judge Frankel found it unlikely that Bergman would ever offend again. This leaves only the economic argument of optimal deterrence. Would it have been possible to achieve optimal general deterrence by only fining Bergman and Milken. The Judges ruled not, but I suspect that many economists would argue that given the wealth of these two criminals a large enough fine would have effectively deterred others.

This leaves Judge Frankel's second argument, equal justice. Economists are not accustomed to thinking about equal justice, but are accustomed to thinking about horizontal equity. As we have argued earlier, in the criminal justice setting, horizontal equity might be seen as treating equally guilty parties equally. Sending the judgmentproof poor to prison and allowing the equally guilty rich to pay a fine might strike some economists as horizontally inequitable. 


\section{PUBLIC AND PRIVATE PROVISION OF PREVENTION AND CRIMINAL JUSTICE}

The previous section gave reasons why we might have public expenditures on crime prevention and criminal justice. In this section we will focus on [1] how much overall spending there should be on crime prevention and criminal justice [2] public expenditures on crime prevention and criminal justice [3] individual crime prevention activities and [4] the partial privatization of criminal justice activities.

\section{Optimal level of expenditures on crime prevention and criminal justice}

In many industrialized countries, an increasing amount of public and private resources is devoted to crime prevention. What counts as prevention? Examples include, specific crime prevention programs (e.g., juvenile delinquency, school, ex-offender job training, rehabilitation and counseling programs), employment of security guards, installation of locks, burglar alarms, CCTV systems and many other innovations in crime preventive technology and policing. The socially or individually optimal level of crime prevention is where the marginal benefit of reduction in crime equals the marginal cost of extra prevention. However, as Freeman (1999) has noted, to estimate the marginal dollar value of the reduction in crime due to any crime prevention policy is hard because of the difficulties associated with measuring reductions in monetary and non-monetary costs (e.g. reduced non-monetary loss from being victimized).

To calculate the tradeoff of the marginal value of the reduction in crime due to the criminal justice system is even trickier than for prevention. The criminal justice system is diverse and multifaceted. There are a host of agencies involved and at the margins these agencies engage in much work having little to do with criminal justice. Thus, when the youth services of an English town asked the simple question "did our interventions against offending come to a profit or loss last year" the answer required a considerable research effort. A criminal justice 'audit' was set in train to estimate costs of operating the criminal justice system. For a discussion of such an audit see Shapland (2000). Shapland notes that such work helps us to understand the respects in which criminal 
justice is indeed a 'system'. Efforts to gauge precisely the unit cost of each stage of criminal justice (e.g., average costs to provide support to victims during the reporting and investigation stage) have a wider significance. Only by comparing the use of resources with such data can one see the effective priorities of the system, that is, upon what it spends its money. Informed comparison of, say, spending on victim/offender mediation compared with spending on refuges for rape victims, can then be made.

Interest in rigorous evaluations of crime prevention programs has increased in recent years. Sherman et al., (1997), for example, introduces a scientific methods scale to assess the methodological quality of evaluation studies in the US, and Goldblatt and Lewis (1998) report similar research from the UK. Partially in response to this trend, the UK Government established a three-year Crime Reduction Programme (1999-2002) which included an assessment of the effectiveness and cost-effectiveness as a foundation for setting priorities and allocating resources. Cost-effectiveness and cost-benefit analyses of criminal justice agencies and programs require both estimates of the costs of crime and the cost of the agency or program. As noted earlier, estimating the cost of crime is difficult. However, estimates are becoming more common. For example, Brand and Price (2000) provide estimates of the cost of crime for the UK, which include monetary and non-monetary costs to victims. Cost-benefit analyses of crime prevention programs have also been carried out in other industrialised countries (see references cited in Brand and Price).

There appears to be a broad consensus in the international community on the process required to ensure cost-effectiveness in reducing crime: increased collaboration between institutions (see Walker and Sansfacon 2000). These institutions include communities, families, schools, businesses, and government agencies, such as, law enforcement, education, health, labour, social services, housing and urban planning. For France, Walker and Sansfacon provide confirmation of the importance of coordination of crime prevention programs between government agencies in reducing crime. The authors describe "Local Prevention Contracts" in which mayors, chief prosecutors, police chiefs and the national official for education sign contracts to support local crime prevention projects covering most urban areas in France. Also, a community might end up with a 
group of young workers who share the experience of work with police as safety and security assistants or as social mediation agents.

In addition to increases in partnerships with other organizations, there has been some interesting work on police tactics. On the one hand, the Kansas City preventive patrol experiment (Kelling 1977) concluded that reduced police response time does not reduce crime. On the other hand, community policing with a clear focus (e.g., directed police patrol in crime hot spots) has shown substantial evidence of crime reduction in the US (Sherman et al., 1997). Despite the fact that there is evidence that many different crime prevention programs can effectively pevent crime (see Section V below), police and prisons remain the two most fiscally important areas of criminal justice expenditure in almost all developed countries.

\section{Public Expenditures}

In analyzing expenditures on criminal justice, it should be borne in mind that in most countries, police, courts, and prisons are administered by many different agencies or departments of government. Consequently, within countries it is difficult to identify expenditures since financing is often conducted in separate government departments which may be unrelated to criminal justice itself (see Newman, 1999, pp.137-138). It should also be noted that while information problems concerning annual expenditures on criminal justice exist within countries over time, comparisons at cross-national level are sometimes even more problematic. These difficulties arise, in the main, from the way different countries define crime, justice, and other relevant concepts (see Howard et. al, 2000 , for a survey of comparative criminology issues) ${ }^{6}$.

According to the Bureau of Justice Statistics, the total amount spent by all levels of government in the US in 1996 was \$120 billion. Lindgren and Gifford (2000) report that $\$ 53$ billion was for police protection, $\$ 41$ billion for corrections (e.g., prisons and jails) and \$26 billion for judicial and legal costs. In the U.S., government spending on crime as a percentage of GDP was roughly $1 \frac{1}{2} \%$ in 1996 . Tables 1 and 2 summarize the estimates of criminal justice expenditures for a number of major industrialized countries.

\footnotetext{
${ }^{6}$ Clearly, differences in accounting practices may seriously affect capital and labour expenditure estimates reported by countries to agencies, such as, UNCJS.
} 
These cross-country aggregates are from van Dijk and de Waard (2000) and relate mainly to 1997 and 1998.

The US and England and Wales have the highest levels of spending on crime as a proportion of GDP with Denmark and France recording the lowest expenditure rates. A striking feature of Table 1 is the relatively low level of police expenditure for the US compared with the high level in England and Wales. This difference may reflect the high ratio of private to public police in the US relative to England and Wales, but may also reflect differential salary levels within and across these countries.

It is no surprise that the expenditure on prisons is much higher in the US than in other countries given the substantial increases in the US incarceration rate over the last three decades. For purposes of comparison, expenditures rates on prisons in France are the lowest in the sample.

TABLE 1

Estimate of Expenditures per mille of GDP, 1998 prices

\begin{tabular}{|l|l|l|l|l|l|}
\hline & Judiciary & Prosecution & Police & Prison & Total \\
\hline Australia & 1.12 & 0.28 & 7.37 & 1.76 & 10.53 \\
\hline Austria & 2.49 & 0.17 & 8.79 & 1.15 & 12.60 \\
\hline Canada & 1.20 & 0.34 & 7.23 & 2.48 & 11.25 \\
\hline Denmark & 1.22 & 0.21 & 4.86 & 1.35 & 7.64 \\
\hline England and Wales & 1.24 & 0.46 & 10.82 & 2.55 & 15.07 \\
\hline France & 1.05 & 0.26 & 6.10 & 0.85 & 8.26 \\
\hline Germany & 2.72 & 0.79 & 5.86 & 1.06 & 10.43 \\
\hline Netherlands & 1.12 & 0.56 & 7.30 & 2.59 & 11.57 \\
\hline Sweden & 1.67 & 0.42 & 6.07 & 2.18 & 10.34 \\
\hline US & 2.91 & 0.47 & 6.75 & 5.51 & 15.64 \\
\hline
\end{tabular}

Note: Estimates are italicized.

Source: van Dijk and de Waard (2000) p.49.

From Table 2 we note that the US is the biggest per capita spender with expenditures of $€ 436$ per head, followed by Austria and England and Wales. The lowest per capita spenders were France and Denmark with $€ 180$ and $€ 184$, respectively. 
TABLE 2

Estimate of Expenditures per capita in $€, 1998$ prices

\begin{tabular}{|l|l|l|l|l|l|}
\hline & Judiciary & Prosecution & Police & Prison & Total \\
\hline Australia & 25 & 6 & 160 & 38 & 229 \\
\hline Austria & 57 & 4 & 203 & 26 & 290 \\
\hline Canada & 28 & 8 & 169 & 58 & 263 \\
\hline Denmark & 30 & 5 & 117 & 32 & 184 \\
\hline England and Wales & 23 & 9 & 205 & 49 & 286 \\
\hline France & 23 & 6 & 132 & 19 & 180 \\
\hline Germany & 64 & 19 & 137 & 25 & 245 \\
\hline Netherlands & 23 & 11 & 151 & 54 & 239 \\
\hline Sweden & 33 & 8 & 119 & 43 & 203 \\
\hline US & 81 & 13 & 188 & 154 & 436 \\
\hline
\end{tabular}

Note: Estimates are italicized. Fixed exchange rates for $€$ zone countries and PPP 1998 for other countries. Source: van Dijk and de Waard (2000) p.50.

During the past two decades, the number of police per head of population for both industrialized and developing countries has increased, although the greatest increases have been seen in industrialized countries. As Newman (1999) points out, there exists a strong positive correlation between expenditure on criminal justice and economic wealth (as measured by GDP per capita). Table 3 focuses on police expenditure per capita and GDP per capita. In general, we see that richer countries spend more on policing.

However, Japan is one clear exception with a very high GDP but low police expenditures. 
TABLE 3

Police Expenditure and GDP, 1994 (per capita US \$)

\begin{tabular}{|l|c|c|l|}
\hline Country & $\begin{array}{l}\text { GDP (US \$) } \\
\text { per capita }\end{array}$ & $\begin{array}{l}\text { Expenditure on } \\
\text { Police (US \$) } \\
\text { per capita }\end{array}$ & $\begin{array}{l}\text { Expenditure on } \\
\text { Police as a } \\
\text { percentage of GDP }\end{array}$ \\
\hline Colombia & 1847 & 18.72 & 1.01 \\
\hline Costa Rica & 2463 & 7.42 & 0.30 \\
\hline Croatia & 3867 & 20.57 & 0.53 \\
\hline Cyprus & 9754 & 136.59 & 1.40 \\
\hline Denmark & 28245 & 145.28 & 0.51 \\
\hline Finland & 19048 & 112.23 & 0.59 \\
\hline France & 24608 & 148.90 & 0.61 \\
\hline Greece & 7465 & 60.01 & 0.80 \\
\hline Hong Kong & 22590 & 185.65 & 0.82 \\
\hline Hungary & 4072 & 6.09 & 0.15 \\
\hline India & 309 & 0.20 & 0.06 \\
\hline Japan & 36782 & 18.40 & 0.50 \\
\hline Jordan & 1095 & 15.42 & 1.41 \\
\hline Madagascar & 208 & 0.05 & 0.02 \\
\hline Malta & 7394 & 77.09 & 1.04 \\
\hline Netherlands & 21536 & 204.09 & 0.94 \\
\hline Romania & 1274 & 4.13 & 0.32 \\
\hline Saint V. \& Grenadines & 2248 & 41.45 & 1.84 \\
\hline Singapore & 23556 & 100.94 & 0.43 \\
\hline Slovenia & 7206 & 98.13 & 0.70 \\
\hline Spain & 2201 & 27.73 & \\
\hline Sweden & 157.29 & \\
\hline
\end{tabular}




\begin{tabular}{|l|r|r|l|}
\hline Switzerland & 36096 & 299.53 & 0.83 \\
\hline Turkey & 2227 & 9.66 & 0.43 \\
\hline
\end{tabular}

Source: Adapted from Newman (1999) p.302

The table above tells us that richer countries spend more on police per head. However, rough calculations suggest that developing countries (e.g., Colombia, Cyprus, Jordan, Saint V \& Grenadines and Solvenia) spend more on police as a \% of GDP relative to industrialized countries. ${ }^{\text {[ }}$

Rapidly growing prison populations in many countries has led to an upsurge of interest in discerning the impact of this costly increase on crime rates. For example, recent work in the US, using either state-level panel data on crime rates from the FBI's Uniform Crime Reports (e.g., Levitt, 1996) or time-series data (e.g., Witt and Witte, 2000), finds increased imprisonment to be associated with significant declines in the reported crime rate. It is important to note that this work considers the effect of increased imprisonment on crimes reported to the police. As noted earlier, reported crime can change even when actual crime does not. For example, victims can decide to report more or less crime to the police and the police can decide to record more or less of the crime that they uncover.

As of midyear 1999, the US had incarcerated 1,860,520 individuals in its prisons and jails. This represents an incarceration rate of 1 in every 147 US resident. Estimates of the annual cost of locking up an inmate in the US can be found in Donohue and Siegelman (1998). For example, Donohue and Siegelman (p. 5) estimate that the annual cost of incarcerating an additional inmate is approximately $\$ 36,000$ (in 1993 dollars). Although this estimate includes cost of building, occupying a prison cell and lost legitimate wages, it ignores a number of social benefits (e.g., the benefit from seeing an individual punished) and social costs (e.g., effects of imprisonment on future legitimate work experience).

Not surprisingly, there are vast differences in expenditure on prisons between developed and developing countries. As well as differences in expenditure on police and courts between developed and developing countries, richer countries also tend to spend

\footnotetext{
${ }^{7}$ In some countries, the military assumes some police functions. For example, in the US, the military was used to help fight the "war on drugs".
} 
more on prisons, although Japan again, with its high GDP spends relatively little on prisons (Newman 1999). Table 4 shows UNCJS figures for annual public expenditures per convicted prisoner. These data are derived by multiplying the expenditure (salaries and fixed assets) on corrections (penal and correctional institutions) reported by each country in local currency by an exchange rate and then dividing by the number of convicted adult prisoners reported in 1994. With the exception of Northern Ireland, which has its own unique characteristics, Switzerland is currently one of the highest spenders, alongside Sweden, US, Denmark and England and Wales. Interestingly, these are the same countries identified in Figure 1, p. 4, as having stronger rules of law.

TABLE 4

Annual Expenditure per Convicted Prisoner, 1994 (US \$)

\begin{tabular}{|l|c|}
\hline Northern Ireland & 158197 \\
\hline Switzerland & 112145 \\
\hline *Sweden & 90806 \\
\hline$*$ US & 73205 \\
\hline Denmark & 64932 \\
\hline England and Wales & 61721 \\
\hline Bermuda & 56510 \\
\hline Japan & 47873 \\
\hline Scotland & 46235 \\
\hline Luxembourg & 43885 \\
\hline Cyprus & 39284 \\
\hline Slovenia & 31786 \\
\hline Hong Kong & 28341 \\
\hline Portugal & 22442 \\
\hline Finland & 18908 \\
\hline Austria & 17980 \\
\hline Belgium & 15767 \\
\hline Uruguay & \\
\hline
\end{tabular}




\begin{tabular}{|l|r|}
\hline Rep of Korea & 10122 \\
\hline Hungary & 9788 \\
\hline Singapore & 9593 \\
\hline Czech Rep & 8903 \\
\hline *Brunei Darussalam & 4253 \\
\hline Colombia & 4028 \\
\hline Turkey & 3384 \\
\hline Slovakia & 2962 \\
\hline Panama & 2871 \\
\hline Costa Rica & 1923 \\
\hline Croatia & 1231 \\
\hline Guyana & 542 \\
\hline Madagascar & 70 \\
\hline
\end{tabular}

*1990 data.

Source: Newman (1999) p.142

An examination of expenditures per convicted prisoner indicates some interesting facts. Japan has substantially lower levels of spending on prisons per head of the population, while at the same time, spends a high amount per prisoner. Another fact that stands out is that developing countries have lower levels of prison expenditure per prisoner compared with industrial countries. These particular comparisons are obviously sensitive to the precise choice of day of year, given that the number of admissions to prison is not taken into account (see Newman, 1999, p.337).

\section{Individual Efforts to Prevent Crime}

In general, an individual will purchase crime prevention goods and services when the cost of prevention is less than the expected benefits from prevention. One aspect of the debate over the modes of crime prevention is the separation between private and public expenditures. There are a number of explanations as to why certain individuals may only be concerned about private expenditures. The failure of government programs to stem the growth in crime may provide one example, but an alternative explanation may lie in terms of how individual objectives are determined. The median-voter model, 
originally developed in the political sciences, may be applied to shed light on the level of private prevention expenditures. In democracies, things like police services will be set at the level desired by the median voter (generally considered to be the voter with median income). Individuals and firms with above median income may quite rationally choose to increase their level of protection by buying in the private market. Under such circumstances, it could be argued that richer individuals and firms purchase relatively more protection, because they personally stand to gain more from this than from the alternative low-protection strategy.

Expenditures by individuals and private organizations on crime prevention are more difficult to estimate than public expenditures. In 1992, the latest year in the US for which we have a benchmark input-output table, private household purchases of detective and protective services was $\$ 944$ million and purchases of security systems services was $\$ 1301$ million. Clearly, these are not the only private purchases related to crime prevention and criminal justice. Purchases of legal services by private households was about $\$ 44$ billion in 1992, but we have no information on what part of this was related to criminal cases. There are also expenditures on modifications to existing structures (e.g., bars on windows) car alarms, and other anti-theft devices that do not show up explicitly in the estimates. The above private expenditures do not include expenditures by businesses and other organizations. Such organizations have substantial crime prevention and apprehensions expenditures as is clear from a trip to any major company or university. Unfortunately, such estimates are not readily available in the UK due to the absence of systematic accounting of private crime prevention expenditures.

Cooter and Ulen (2000) on p. 458, quote figures for US private expenditures on crime prevention in 1993 of $\$ 65$ billion. Sources cited in Anderson (1999) estimate that expenditures on private protection in 1993 are $\$ 69$ billion. Philipson and Posner (1996) cite a yet higher estimate of $\$ 300$ billion (includes expenditures by businesses and other enterprises on security guards and other measures of self-protection). Laband and Sophocleus (1992) provide a similar estimate.

Anderson concludes that the aggregate burden of crime, taking into account the value of lost property, transfers, and losses to victims of crime (e.g., worth of assets from victims, lost productivity, medical expenses, and diminished quality of life), is $\$ 1,705$ 
billion. This estimate seems excessive given it is approximately one-fifth of the US GDP reported in 1999.

It would appear that private and public anti-crime initiatives can be either substitutes or complements. Philipson and Posner, for example, show that the proportion of homes with burglar alarms in a state falls with improved public sector crime protection schemes. Ayres and Levitt (1998) find that the introduction of a Lojack system for recovering stolen cars reduces overall car crime.

Measures of the cost of crime and of private expenditures on crime prevention and criminal justice are sparse and, yet, such numbers are central to being able to talk intelligently about either the public/private tradeoff or the optimal level of overall expenditures on crime prevention and criminal justice. This is an area ripe for detailed and carefully done empirical work.

\section{Partial Privatization of Criminal Justice Activities}

What role does the private sector play in the criminal justice system? The American example is perhaps the most dramatic in the variety of private sector activities that characterize its criminal justice system. Benson (1998) provides a comprehensive account of the public sector contracting out to the private sector. Examples of this partial privatization include police services, drug treatment facilities, airport security, prisons and correctional facilities.

It is now commonplace for private firms to provide a whole range of services previously supplied by governments. Corrections Corporation of America and Wackenhut Corrections Corporation, for example, provide correctional, security and other related services to government agencies around the world. Wackenhut contracts include, security at the US Embassy in El Salvador, supplying the entire police force for a nuclear power plant in Illinois and providing correctional facilities in New Zealand.

Benson provides evidence to show that private security and community policing initiatives have been extremely successful in reducing crime. Examples include, private residential streets, patrols and neighborhood watch, the deterrent effect of gun

\footnotetext{
${ }^{8}$ We have been unable to find estimates of private expenditure on crime prevention goods and services for other countries.
} 
ownership ${ }^{2}$, and technology (Lojack example mentioned above). In addition to these private sector efforts, he argues that the criminal justice system should employ more resources in giving reparation for loss or injury inflicted to the victims of crime. Benson notes that private sanctions imposed by firms (e.g. firing an employee who steals from the firm) are now being substituted for public sector criminal prosecution.

The contracting out by governments around the world of prison management services to private companies has grown rapidly over the last decade. As figure 6 documents, the total number of prisoners held in private facilities rose sharply from 15,300 in 1990 to 145,160 in 1999. For example, the number of private prisoners in the US has grown from about 1200 in 1985 to 122,871 at the end of 1999, which represents $6.6 \%$ of total prison population. Estimates of the number of private prisoners in other

\footnotetext{
${ }^{9}$ The deterrent effect of private gun ownership is very controversial. See Cook \& Ludwig (2000). As a whole Benson's book has been the subject of considerable controversy. It would be very useful to have scholars with different perspectives consider the benefits and costs of privatisation of crime prevention and criminal justice.
} 


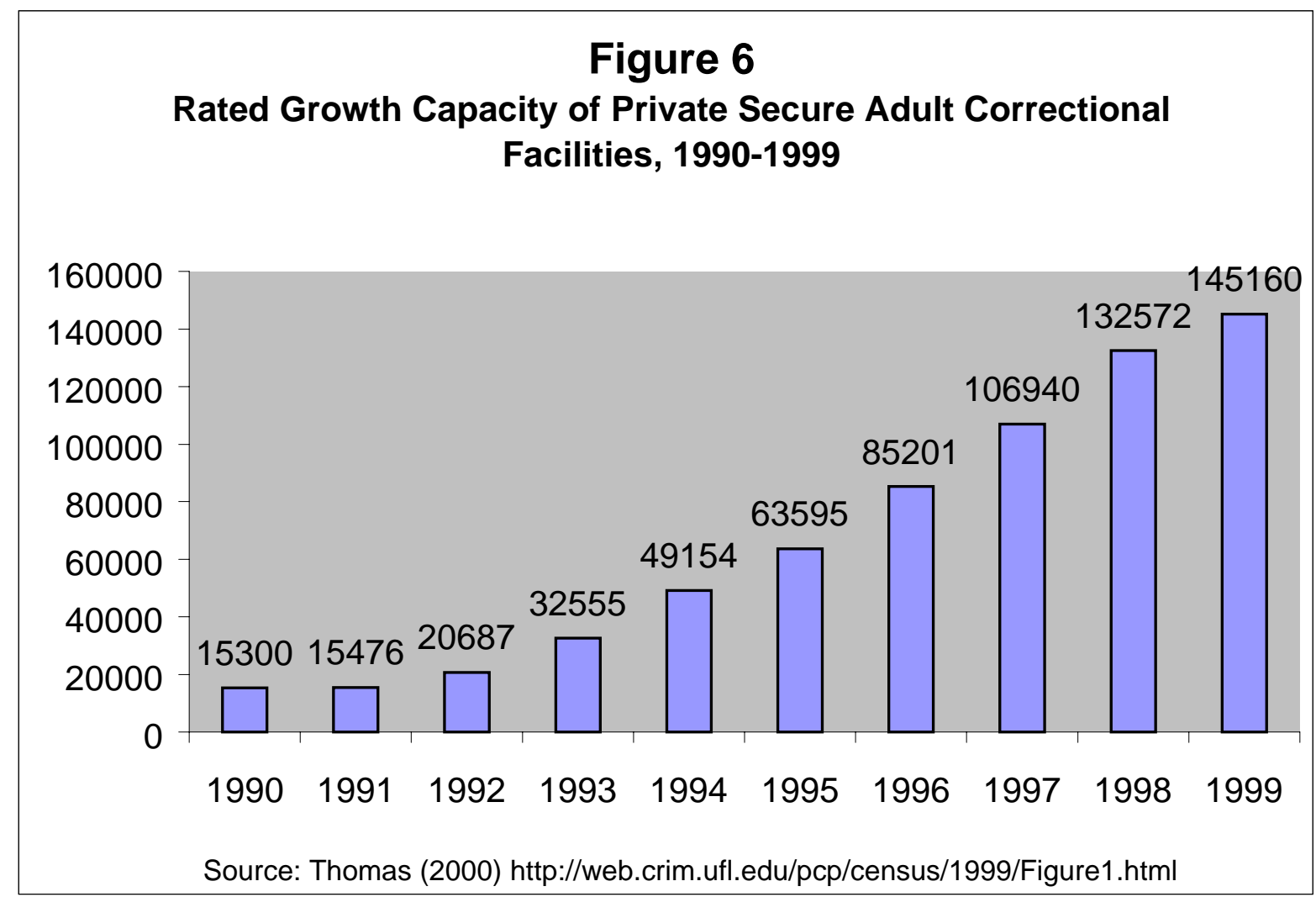

countries, at end of 1999, are Australia (7459), England and Wales (7161), Netherlands (737), New Zealand (384), Scotland (500) and South Africa (6048). With the exception of Australia, these totals are very small relative to the total number of prisoners.

The US, Australia and the UK have been the main countries to experiment with private prisons. At the end of 1999, the number of privately managed secure adult facilities in the US, Australia and the UK were, 158, 15 and 10, respectively. Corrections Corporation of America and Wackenhut Corrections Corporation have the largest global market share of contracts to run private prisons.

Owing perhaps to the rise of privatizing governmental functions and to the claim that private prisons are cheaper per prisoner than public prisons, the issue of privatization of prisons has become highly contentious (see, for example, Shaw 1994, Biles 1997, Hart et al. 1997, and Benson 1998). Arguments for governments to manage prisons generally rest on the need to maintain a high level of standards in the quality of prison services and in the behavior of prison employees. Contracts for private prison operators would tend to 
be quite incomplete; privately contracted firms would have strong incentives to lower standards in order to minimize costs (Hart, et al, 1997). There are a number of recent examples where this has actually happened. A prison in Louisiana was recently taken away from the private sector because of unacceptable conditions. Others argue that it is not necessarily the contractual incompleteness that has an adverse effect on quality, but rather the inability or unwillingness of the client to enforce contract terms (Domberger and Jenson, 1998).

There has been a substantial growth in private policing in many countries. As Newman observes, "While private policing has a long history in industrial countries, it is also becoming a major growth industry in emerging market economies" (1999, p.126). Sources cited in Newman (1999) estimate that the number of security guards in Singapore (with a population of 2.6 million) is approximately 15,000 to 20,000 , which is at least twice the police strength. A high ratio of private to public police is also found in other developed economies. For example, the US has a security guard (or officer)/police ratio of three to one (see Newman p.127).

\section{WHAT WE KNOW ABOUT THE RELATIVE EFFECTIVENESS OF CRIME PREVENTION AND CRIMINAL JUSTICE}

Just how effective are specific crime prevention programs? What are the major benefits of incarceration? In this section we do two things. First, we survey briefly a range of crime prevention strategies that seem to work in the US. Second, we look at the arguments that have been put forward relating to the economic issues surrounding the benefits of incarceration. Standard texts on law and economics (e.g., Cooter and Ulen, 2000) discuss four types of social benefits derived from imprisonment, namely, retribution, rehabilitation, deterrence and incapacitation. Given the difficulty of measuring the first two, we shall concentrate on deterrence and incapacitation. It should be noted, however, that much of the empirical literature does not distinguish between deterrence and incapacitation effects. In the case of imprisonment, separating 
incapacitation from general deterrent effects is difficult since the two are jointly produced.

\section{Specific Crime Prevention Programmes}

Potential effective crime prevention programmes could take a number of forms. Sherman et al., (1997), writing from a US perspective, points to a number of successful programmes. These include, community based mentoring and afterschool recreation programmes, intensive work with at-risk families with young children, intensive residential training programmes for at-risk youth, extra police patrols in high-crime hot spots and a number of situational crime prevention schemes, such as neighbourhood watch and building and community redesign programmes.

The recently completed evaluation of Children at Risk (CAR) programme found that youths in the treatment group had participated in more social and educational activities, exhibited less antisocial behaviour, committed fewer violent crimes and used and sold fewer drugs than did youths in the control group (see Harrell, Cavanagh and Sridharar 1999). CAR was a drug and deliquency prevention program for high risk adolescents between the ages of 11 and 13 who lived in five cities (Austin, Bridgeport, Memphis, Savannah, and Seattle). The programme consisted of eight components considered key to comprehensive delinquency prevention: case management, family services, educational services, after-school and summer activities, mentoring, incentives, community policing and enhanced enforcement, and criminal-juvenile justice intervention. One interesting result was that the positive effects of the programme on drug use, crime, and risk factors were not generally observed at the end of the programme. This may indicate that CAR was simply a secondary prevention programme when youths got into trouble.

The Job Corps programme in the US has long been a central part of the federal government efforts to provide training for disadvantaged youths. Recent evidence suggests that participation in the programme significantly reduced arrest and conviction rates, as well as time spent in jail (see Schochet, Burghardt and Glazerman 2000). The arrest rate was reduced by about 6 percentage points and the impacts on arrest rates were very similar across male and female subgroups. 
The evaluation of the effectiveness of private crime prevention activities is much more difficult to find. However, given the recent epidemic of households and firms buying locks or alarms or other forms of protection in response to the threat of crime, researchers have started considering how these activities can have negative or positive spillover effects for the neighbourhood community. For example, Ayres and Levitt (1996) conclude that the Lojack system for recovering stolen cars (hidden radiotransmitter that enables the police to locate the stolen vehicle) provides an example of a positive externality due to a general deterrent effect.

Related to the above initiatives are those of how communities organise themselves when allocating resources to crime prevention programmes. Hawkins (1999), for example, explores the implications of a "Communities That Care" system where prevention science is used to guide the type of prevention policies suitable according to profiles of risk and protection.

\section{Deterrence}

There is a reasonably large theoretical and empirical literature in economics that considers both the deterrent (specific and general) and incapacitative effect of imprisonment. For example, economists and others have sought to discern if increased imprisonment lowers the crime rate? How does the deterrent effect of formal sanctions arise?

Following Becker's theoretical work, much empirical work by economists has focused on the role of the criminal justice system in determining criminal activity. In short, economists have argued, using both theory and empirical work, that if the cost of crime is raised, by increasing the probability of apprehension or imposing more or longer sentences, less of it will occur. ${ }^{10}$ Deterrence refers to the effect of possible punishment on individuals contemplating criminal acts $\frac{11}{1}$. Deterrence may flow from both criminal justice system actions and from social actions (i.e., the negative response of friends and associates to criminal behavior). To date, attempts by economists to measure deterrent effects have concentrated on the effects of the criminal justice system while work by

\footnotetext{
${ }^{10}$ Actually the deterrence hypothesis was widely explored both empirically and theoretically prior to economists re-entry to the study of crime in the late 1960s.

${ }^{11}$ Marginal deterrence refers to a situation where individuals commit less harmful rather than more harmful acts if expected sanctions rise with harm (see Polinsky and Shavell, 1999).
} 
sociologists have concentrated on "social sanctions." See Nagin (1998) for a survey of this literature.

The potential criminal's perceptions regarding social sanctions are difficult to measure, although work on peer group (e.g., Evans, et al, 1992) and community effects (e.g., Sampson and Groves, 1989) may be able to capture some aspects of perceived social sanctions. In terms of the effects of education, a consistent finding is that students who attend schools with strong ethical values (e.g., parochial schools) offend less than students attending modern urban high schools (see, e.g., Tauchen et al. 1994). This effect may stem from higher levels of social sanctions against crime in schools with strong ethical standards or from the better family and community settings of at least some students.

In an interesting paper, Williams and Sickles (1999) provide an extension of Ehrlich (1973) by including an individual's social capital stock into his utility and earnings functions. Social capital, including things like reputation and social networks, is used as a proxy to account for the effect of social norms on an individual's decision to participate in crime. This assumes that the stigmatism associated with arrest depreciates an individual's social capital stock. Williams and Sickles clarify this point further by arguing that employment and marriage create a form of state dependence, which reduces the likelihood of criminal involvement. In other words, an individual with a family, job or good reputation has more to loose if caught committing crimes than those without such attachments. Dynamics arise from current decisions affecting future outcomes through the social capital stock accumulation process. Their main result is that criminals behave rationally in the sense that they account for future consequences of current period decisions 12 .

Glaeser, Sacerdote and Scheinkman (1996 p. 543) make a similar point in the context of family structures, claiming "the average social interactions among criminals are higher when there are not intact family units. The presence of strong families interferes with the transmission of criminal choices across individuals". The importance of family structure (along with other variables such as deterrence and returns to crime) in explaining urban crime is also the key point of Glaeser and Sacerdote (1999).

\footnotetext{
${ }^{12}$ Many of these insights into the dynamics of crime were originally discussed in Williams PhD dissertation (1995)
} 
In the literature deterrence is broken into two components. The first component, called specific deterrence, encompasses the effect of punishment on the individual punished. The second component, called general deterrence, encompasses the effect of punishment on the general public. Specific deterrence is generally reflected by including measures that reflect the individual's past experience with the criminal justice system (e.g., Witte 1980; or Trumbull 1989). The implicit assumption is that offenders from their perceptions regarding possible punishment based on their own experience with the criminal justice system ${ }^{13}$. For example, the offender's perceived probability of arrest might be proxied by the ratio of his past self-reported offenses to arrests and his perceived punishment as some sort of average of the punishments he has received in the past. There is an important potential difficulty in using this type of specific deterrence measure. If there is autocorrelation in criminal behaviour, these measures of specific deterrence will be correlated with the error term in the crime equation. One might instrument these variables by using community-level or peer group measures.

It has proven much more difficult to obtain reasonable measures of general deterrent effects. As an example, consider the probability of arrest. In a standard model of criminal choice, an individual's probability of arrest depends upon his level of criminal activity, his ability to avoid arrest, and exogenous factors related to the criminal justice system. When contemplating a crime, the individual is faced with a schedule of probabilities that relates the nature and extent of his criminal activity to the probability of arrest. See Cook (1979) or Tauchen et al. (1994) for a discussion. An analogy would be to a taxpayer who, when making her labour supply and tax reporting decisions, is faced with a schedule that relates reported income to the schedule of tax rates.

Just as there is no single tax rate, there is no single probability of arrest. There is a different probability of arrest for each and every possible set of criminal choices. For example, we would expect that for a given individual the probability of arrest would be much higher for robbery than for petty theft.

\footnotetext{
${ }^{13}$ We know little about how individuals form their perceptions of likely sanctions if they offend, although Paternoster and his colleagues (see, e.g., Nagin and Paternoster, 1991) have done interesting empirical work, and Sah (1991) has developed a model for the perceived probability of punishment. In a study of institutionalised young adults (college students and prison inmates), Lattimore et al. (1992) find that individuals transform probabilities when making risky choices. Risk seeking is common over long-shot odds, and subjects are less sensitive to changes in midrange probabilities than is assumed by expected utility models.
} 
Changes in criminal justice policy or in the level of criminal justice resources alter the probability schedule facing a potential criminal. For example, an increase in criminal justice resources such as that contained in the 1994 US Crime Bill might raise the probability of being arrested for each criminal act, that is. It might cause the schedule relating the probability of arrest to criminal activity to shift up. The "war on drugs" caused certain sections of the probability schedule (the sections associated with drug offenses) to shift up and other sections to shift down (the sections associated with violence offenses). It is these types of exogenous changes in the criminal justice system that should be used to reflect deterrent effects and not a community-level probability of arrest. This approach to representing deterrence has been used by Block et al. (1981) and Tauchen et al. (1994).

There are a number of practical problems that arise in testing for deterrent effects. In particular, we consider three estimation issues: measurement error, endogeneity and nonstationarity.

Models of criminal behaviour are usually estimated using official reported crime statistics. Such recorded offences are influenced both by victims' willingness to report crime and by police recording practices and procedures. At the level of the individual police department, both administrative and political changes can lead to abnormalities in reported data or to failures to report any data. For example, the measurement error in crime rates may arise because hiring more police leads to more crimes reported. Consequently, estimates derived from regressing crime rates on the number of police (or on arrest rates) may be severely distorted by the impact of measurement error. Until quite recently, measurement error was not widely considered in the economics literature. However, the importance of the issue and potential solutions were considered very early by Carr-Hill and Carr-Hill (1972) and Carr-Hill and Stern (1973).

More recently, Corman and Mocan (2000) report that complaints to the police for murder, robbery, burglary and motor vehicle theft "decline in response to increases in arrests." They use detailed information from the New York Police Department and modern time series estimation techniques. By using data for a single police department, they avoid some of the measurement error inherent in studies that use cross department statistics. However, changes in victim reporting behaviour are not considered. 
Murder is the one crime for which police reports are quite good. Corman and Mocan report that the elasticity of murders reported to the police with respect to the arrest rate is approximately -.3. A number of authors have noted recently that much of the decline in murder rates in developed countries has stemmed from a decrease in domestic assaults. Corman and Mocan do not include measures to reflect the change in public and police attitudes regarding domestic violence in their equations. In general, economists' work on crime are only beginning to incorporate family and community effects.

Somewhat unsurprisingly, economists have concentrated their attention on the possibility that crime and sanctions are jointly determined. The main point is that increases in sanctions may cause decreases in crime, but increases in sanctions may also be a response to higher crime rates. Since the 1970s there has been a considerable effort to find instruments (i.e. exogenous factors) to identify the effects of sanctions on the supply of crime. For example, Levitt (1996) uses instrumental variables to estimate the effect of prison population on crime rates. Prison-overcrowding litigation in a state is used as an instrument for changes in the prison population.

In order to identify the effect of police on crime, Marvell and Moody (1996) and Levitt (1997) proposed different procedures. Marvell and Moody are concerned with the timing sequence between hiring police and crime. Using lags between police levels and crime rates to avoid simultaneity, they test for causality in the spirit of Granger (1969). Although they find Granger causation in both directions, the impact of police on crime is much stronger than the impact of crime on police. In a recent paper Levitt (1997) uses the timing of elections (when cities hire more police) as an instrumental variable to identify a causal effect of police on crime. He finds that increases in police, instrumented by elections, reduces violent crime, but have a smaller impact on property crime. Levitt does not consider the impact of elections on either victim or police reporting behaviour.

A substantial problem that has been ignored in the vast majority of empirical studies is nonstationarity of crime rates. A time-series is said to be nonstationary if (1) the mean and/or variance does not remain constant over time or (2) covariance between observations depends on the time at which they occur. In the US, the index crime rate appears strongly nonstationary (see, for example, Witt and Witte 2000). Here, the authors have attempted to estimate and test a model using time-series cointegration techniques. 
The empirical results suggest a long-run equilibrium relationship between crime, prison population, female labour supply and durable consumption.

\section{Incapacitation}

Incapacitation refers to when an offender behind bars cannot commit new crimes

against members of society outside prison $\frac{14}{4}$. Therefore, unless there is an infinitely elastic supply of criminals, incapacitation will reduce crime over what it would otherwise have been. However, as argued in section II with respect to drug dealers, if the supply of offenders is reasonably elastic the incapacitation effect may be very small (see Freeman 1996). In addition, for some individuals, incarceration may only affect the timing rather than the total number of crimes they commit.

These uncertainties of the effects of prison on crime are illustrated in a recent report by the Justice Policy Institute (2000) on incarceration and crime trends in Texas. As of year end 1999, there were 706,600 Texans in prison, jail parole or probation, the largest population of inmates under the jurisdiction of its prison system in the U.S. However, there is little evidence that Texas' severe correctional system is responsible for the fall in crime; Texas crime rates have not experienced the declines witnessed in other parts of the U.S., where prison growth has been much slower.

The basic intuition of the optimal sanction is that individuals should be put in prison and kept there as long as the expected net harm exceeds the costs of imprisonment. Polinsky and Shavell (1999) argue that prison should only be used to incapacitate individuals whose net harm is relatively high. In addition, these authors highlight two points about incapacitation. First, since expected harm caused by individuals usually declines with their age, it may be worth having fewer older people in prison. Second, past behavior is the best predictor of future behavior. Thus, the criminal justice system should impose a prison sentence on someone who has committed a harmful act rather than incapacitating someone who has the potential to commit a crime. In practice, you have to commit a crime to go to prison.

While the theory of optimal incapacitation policy is well established (see Shavell 1987), the empirical work faces some difficulties. The central difficulty is how to

\footnotetext{
${ }^{14}$ As discussed in Polinsky and Shavell (1999), incapacitation can take forms other than imprisonment e.g., loss of a driver's license prevents an individual from doing harm while driving.
} 
separate the deterrent and incapacitation effects associated with imprisonment. One approach, discussed at length in Ehrlich (1981), is to compare regression estimates of the actual effect of imprisonment on crime with theoretical estimates of maximum incapacitation effects. Some authors, such as Levitt (1998), seek to identify some observable substitution effects of the probability of arrest for one crime on the incidence of a substitute crime. Other authors, such as Kessler and Levitt (1999), have used California's adoption of "three strikes and you're out" sentencing rules to separate the deterrence and incapacitation effects of punishment.

Recently, some researchers have focused their attention on whether sanctions depend on offense history. Glaeser and Sacerdote (2000) provide evidence to show that repeat offenders are more likely to receive longer sentences. Offenders with a high expected probability of recidivism are more likely to commit crimes in the future and thus more likely to be worth incapacitating by imprisonment. Glaeser and Sacerdote use a variety of data sources to examine the sentences given to murderers in the U.S. They find that sentences are longer when there is a greater value to incapacitation or greater deterrence elasticity. However, contrary to the predictions of the economic model of optimal punishment, they find victim characteristics are important in explaining sentencing among vehicular homicides (e.g., drivers who kill women get 56 percent longer sentences, whereas, drivers who kill blacks get 53 percent shorter sentences).

\section{CONCLUSIONS AND SOME SUGGESTIONS FOR RESEARCH}

Crime is pervasive. However, the extent of crime is hard to measure. Cross nationally, we have the best measures for murder. However, even for murder estimates from different sources can vary widely (see Figure 4). Given differences in criminal laws, defendant protections and statistical systems, broad measures of law abidingness (e.g., those developed by the World Bank), and cross-national victimization and self-report surveys offer the best hope of comparing the level of other types of offenses across countries. Crime statistics coming from the criminal justice system (e.g., offenses 
reported to the police) provide valuable information, but do not generally provide reliable estimates of crime either across countries or across time.

To date, much work by economists on crime has used criminal justice statistics and interpreted these statistics as measures of the underlying level of crime. This first generation work has been valuable, but it is now time to move forward. Two directions appear particularly promising. First, in order to interpret criminal justice data, we need to know more about the behavior of both crime victims and the criminal justices system. For example, in order to properly interpret results that use police reports as a measure of crime, we need to understand both victim reporting behavior and police recording practices. Second, work seeking to estimate the deterrent effects of the criminal justice system could benefit from using sources of data on crime other than data from the criminal justice system (e.g., victimization surveys). Studies that use a number of indicators of crime (e.g., multi-indicator models) are likely to provide more meaningful results than studies that use any single indicator.

To date studies of crime by economists have been focused on relatively few issues (e.g., the deterrent effect of police resources and imprisonment). There have been relatively few studies of the way in which such important criminal justice system entities as prosecutors' offices and public defenders operate. ${ }^{15}$

Most, if not all, criminal justice systems operate with budgets that are not adequate to fully process all cases. To deal with this "overcrowding," one or more agencies are given discretion in how they handle cases. Different criminal justice systems grant differing amounts of discretion to different agencies at different points in time. For example, in the US during the 1960s, judges and parole boards had substantial discretion. The determinate sentencing movement limited the discretion of judges and parole boards. Discretion was not eliminated; it was simply shifted to prosecutors from judges and parole boards. How much discretion in criminal justice system is optimal? Where should the discretion be lodged?

Public finance economists have provided valuable work on optimal taxation. As far as we are aware, there has been little work on optimal criminal law or optimal criminal justice funding. What acts should we criminalize? What is the optimal level of

\footnotetext{
15 There has been some work by economists in the US on plea bargaining.
} 
funding for the police, prosecutors, courts and corrections? What should the split between private and public spending be? While private prisons have received some attention, private policing has received less.

Much criminal justice research has focused on preventing crime through the punitive actions of the criminal justice system (e.g., deterrence, incapacitation). Another line of research has focused on preventing crime by working with high-risk youth. The two lines of research are not well integrated. Yet, an optimal portfolio of crime prevention strategies requires a combination of punitive and supportive efforts. 


\section{REFERENCES}

Anderson, D.A., (1999), 'The Aggregate Burden of Crime', Journal of Law and Economics, vol. XLII, pp.611-642. Argersinger v. Hamilin 407 U.S. 25 (1972).

Aronowitz, A. (2000), 'Germany', World Factbook of Criminal Justice Systems, www.ojp.usdojgov/bjs/pub/ascii/wfbcjger.txt, accessed July 7, 2000.

Ayres, I. and Levitt, S.D., (1998), 'Measuring positive externalities from unobservable victim precaution: and empirical analysis of Lojack', Quarterly Journal of Economics, 113, pp.43-77.

Becker, G. (1968), 'Crime and punishment: an economic approach', Journal of Political Economy, vol. 76, pp.169-217.

Benson, B.L. (1998), 'To Serve and Protect', New York, New York University Press.

Biles, D. (1997), 'Private prisons: welcome or not?', Australian Journal of Forensic Sciences, vol. 29.

Block, M., Nold, F. and Sidak, J. (1981) “The Deterrent Effect of Antitrust Enforcement”, Journal of Political Economy 89:429-45.

Borricand, Jacques. (n.d.). France: World Factbook of Criminal Justice Systems. retrieved from the World Wide Web on October 26, 2000: http://www.ojp.usdoj.gov/bjs/pub/ascii/wfbcjfra.txt

Brand, S. and Price, R. (2000) "The Economic and Social Costs of Crime", Home Office Research Study No.217

Carr-Hill, G. and Carr-Hill R. (1972) "Reconviction as a Process", British Journal of Criminology, 12:35-43.

Carr-Hill, R.A. and Stern, N.H. (1973). 'An Econometric Model of the Supply and Control of Recorded Offences in England and Wales', Journal of Public Economics, 1.2, pp.289-318

Chong, Chee Kin. (2000, May 25). Cisco Escorts and Private Doctors for Convicts. The Straits Times (Singapore). 42 Retrieved November 5, 2000, from Lexis-Nexis database on the World Wide Web: http://web.lexis-nexis.com.

Cook, P.J. (1979), “The Clearance Rate as a Measure of Criminal Justice Effectiveness", Journal of Public Economics, $11: 135-42$.

Cook, P.J.and Ludwig, J. (2000), "Gun Violence: The Real Costs", New York, Oxford University Press.

Cooter, R. and Ulen, T. (2000). Law and Economics, $3^{\text {rd }}$ edition, Reading, MA: Addison-Wesley.

Corman, H. and Mocan, H.N. (2000), "A Time-Series Analysis of Crime and Drug use in New York City", American Ecocomic Review.

Domberger, S. and Jensen, P., (1998), 'Contracting out by the public sector: theory, evidence, prospects', Oxford Review of Economic Policy, vol.13 pp. 67-78.

Donohue, J.J., and Siegelman, P. (1998), 'Allocating Resources Among Prisons and Social Programs in the Battle Against Crime', Journal of Legal Studies, vol. XXVII, pp. 1-43.

Ehrlich, I. (1973) "Participation in Illegitimate Activities: A Theoretical and Empirical Investigation", Journal of Political Economy 81:521-565.

Ehrlich, I. (1981) "On the Usefulness of Controlling Individuals: An Economic Analysis of Rehabilitation, Incapacitation and Deterrence", American Economic Review, 71:307-22.

Evans, W., Oates. W. and Schwab, R. (1992), "Measuring Peer Group Effects: A Study of Teenage Behavior", Journal of Political Economy, 100, pp.966-91.

Freeman, R. (1996), "Why do so many young American men commit crimes and what might we do about it?", Journal of Economic Perspectives, 10:25-42.

Freeman, R. (1999), "The Economics of Crime", Ch. 52 in Ashenfelter, O. and Card, D. (ed.), Handbook of Labor Economics 3: North Holland.

Friedman, D. (2000), Law's Order, Princeton, NJ: Princeton University Press.

Gideon v. Wainwright 372 U.S. 335 (1963).

Glaeser, E.L. and Sacerdote, B. (1999), "Why is There More Crime in Cities?", Journal of Political Economy, 107, S225-S258.

Glaeser, E.L. and Sacerdote, B. (2000), “The Determinants of Punishment: Deterrence, Incapacitation and Vengeance”, NBER Working 7676.

Glaeser, E.L., Sacerdote, B. and Scheinkman, J. (1996), “Crime and Social Interactions", Quarterly Journal of Economics, pp. 507-548.

Goldblatt, P. and Lewis, C. (ed) (1998) Reducing Offending: An Assessment of Research Evidence on Ways of Dealing with Offending Behaviour, London: Home Office Research Study 187.

Granger, Clive 1969, Investigating Causal Relations by Econometric Models and Cross-Spectral Methods, Econometrica 37:424-438.

Groves, W., Newman G. and Corrado C. (1987), 'Islam, modernization and crime: a test of the religious ecology thesis,' Journal of Criminal Justice, vol. 13, pp. 23-29. 
Harrell, A., Cavanagh, S. and Sridharar S. (1999), Evaluation of the Children at Risk Program: Results 1 Year After the End of the Program, U.S. Department of Justice, Office of Justice Programs, Washington DC.

Hart, H. L. A. (1994), 'The Concept of Law', Oxford: Oxford University Press.

Hart, O., Shleifer, A. and Vishny, R. (1997), 'The proper scope of government: theory and an application to prisons', Quarterly Journal of Economics, vol. 112, pp. 1163-1202.

Hawkins, J. D. (1999), 'Preventing crime and violence through communities that care', European Journal on Criminal Policy and Research, vol. 7, pp. 443-458.

Howard, G.J., Newman, G. and Pridemore, W.A. (2000), 'Theory, Method, and Data in Comparative Criminology' in Duffee, D. (eds), Criminal Justice 2000, Measurement and Analysis of Crime and Justice, Vol. 4, pp.139-211, National Institute of Justice.

Justice Policy Institute (2000) "Texas Tough?: An Analysis of Incarceration and Crime Trends in the Lone Star State" http://www.cjcj.org

Jurgen_Tas, J., Terlouw, G. and Klein, M. (eds) (1994), Delinquent Behavior of Young People in the Western World, Amsterdam: Kugler Publications.

Kaplan, J., Skolnick, J. and Feeley, M. (1991), Criminal Justice, $5^{\text {th }}$ Edition, Westbury, NY: Foundation Press.

Kaplow, L. and Shavell, S. (1999), 'Economic Analysis of Law,' NBER Working paper 6960.

Kaufman, D., Kraay, A. and Zoido-Lobaton (1999a), 'Aggregating Governance Indicators', Working Paper, World Bank.

Kaufman, D., Kraay, A. and Zoido-Lobaton (1999b), 'Governance Matters, Working Paper, World Bank.

Kessler, D. and Levitt, S. (1999) "Using Sentence Enhancements to Distinguish Between Deterrence and Incapacitation”, Journal of Law and Economics, XLII:343-363.

Laband, D.N. and Sophocleus, J.P. (1992) 'An Estimate of Resource Expenditures on Transfer Activity in the United States’, Quarterly Journal of Economics, vol. CVII, pp. 959-983.

Lattimore, P.J., Baker, J. and Witte, A.D. (1992) "The Influence of Probability on Risky Choice: A Parametric Examination", Journal of Economic Behavior and Organisation, 17:377-400.

Levitt, S. (1996) "The Effect of Prison Population Size on Crime Rates: Evidence from Prison Overcrowding Litigation" Quarterly Journal of Economics, 111, 319-351.

Levitt, S. (1997) "Using Electoral Cycles in Police Hiring to Estimate the Effect of Police on Crime", American Economic Review, 87, 270-290.

Levitt, S. (1998) "Why Do Increased Arrest Rates Appear to Reduce Crime: Deterrence, Incapacitation, or Measurement Error?", Economic Inquiry, 36:353-72.

Lindgren, S.A. and Gifford, L.S. (2000), Criminal Justice Expenditure and Employment Extracts Program, NCJ 178273. Washington, D.C., U.S. Department of Justice, Bureau of Justice Statistics.

Marvell, Thomas, and Moody, Carlisle 1996, Specification Problems, Police Levels, and Crime Rates, Criminology 34:609-646.Merritt v. Faulkner, United States Court of Appeals, Seventh Circuit, 1983. 697 F.2d 761.

Mayhew, P. Dijk, J.M. (1997). Criminal Victimization in Eleven Industrialized Countries: Key Findings from the 1996 International Crime Victim's Survey: The Hague Ministry of Justice WODC. Retrieved on the World Wide Web on November 2, 2000: http://ruljis.leidenuniv.nl/group/jfcr/www/icvs/data/i_VIC.HTM

Miller, W. (1977), Cops and Bobbies: Police Authority in New York and London, 1830-1870, Chicago: University of Chicago Press.

Mirrlees_Black, C. and Ross, A. (1995a) 'Crime Against Retail Premises in 1993', Research Findings 26, London: Home Office.

Mirrlees_Black, C. and Ross, A. (1995b) 'Crime Against Manufacturing Premises in 1993', Research Findings 27, London: Home Office.

Moriyama, T. (2000), 'Japan', World Factbook of Criminal Justice Systems, www.ojp.usdojgov/bjs/pub/ascii/wfbcjger.txt, accessed July 8, 2000.

Nagin, D. (1998) "Criminal Deterrence Research: A Review of the Evidence and a Research Agenda for the Outset of the 21 Century" in Tonry, M. (ed.) Crime and Justice: An Annual Review of Research Vol.23, pp.1-42. University of Chicago Press.

Nagin, D, and Paternoster (1991) “The Preventive Effect of the Perceived Risk of Arrest”, Criminology, 29:561-73.

Nalla, M. World Factbook of Criminal Justice Systems: Singapore. Washington DC: Bureau of Justice Statistics.

Retrieved November 3, 2000, from the World Wide Web: http://www.ojp.usdoj.gov/bjs/pub/ascii/wfbcjsin.txt.

Newman, Graeme (ed) 1999, Global Report on Crime and Justice, New York: Oxford University Press.

Philipson, T.J. and Posner, R.A. (1996), 'The Economic Epidemiology of Crime', Journal of Law and Economics, vol. XXXIX, pp.405-433.

Polinsky, A. M and Shavell, S. (1999), 'The Economic Theory of Public Enforcement of Law', NBER Working Paper 6993.

Posner, R. (1992), Economic Analysis of Law, $4^{\text {th }}$ edition, Boston: Little Brown and Company.

Sah, R. (1991) "Social Osmosis and Patterns of Crime", Journal of Political Economy, 99:1272-95. 
Sampson, R. and Groves, W. (1989), "Community Structure and Crime: Testing Social-Disorganisation Theory", American Journal of Sociology, 94, pp.774-802.

Schochet, P.Z., Burghardt, J. and Glazerman, S. (2000), National Job Corps Study: The Short-Term Impacts of Job Corps on Participants' Employment and Related Outcomes, Mathematica Policy Research, Inc.

Shapland, J. (2000), "Auditing Criminal Justice" in Fielding, N.G., Clarke, A. and Witt, R (eds) The Economic Dimensions of Crime, pp. 238-250. MacMillan Press and St. Martin's Press, London, New York, 2000.

Shavell, S. (1987) “The Model of Optimal Incapacitation”, American Economic Review: Papers and Proceedings,77: 107-10.

Shaw, S. (ed) (1994), Privatisation and Market Testing in the Prison Service, Prison Reforem Trust, London.

Sherman. L.W., Gottfredson, D. Mackenzie, D., Eck, J., Reuter, P. and Bushway, S. (1997), Preventing Crime: What Works, What Doesn't, What's Promising, U.S. Department of Justice, Office of Justice Programs, Washington, DC.

Smith, S. and DeFrances, C. (1996), Indigent Defense, February, 1996, NCJ-158909, Washington: Bureau of Justice Statistics.

Stigler, G. (1970), 'The Optimum Enforcement of Laws', Journal of Political Economy, vol. 78, pp. 526-536.

Tauchen, H., Witte, A.D. and Griesinger, H. (1994), "Criminal Deterrence: Revisiting the Issues with a Birth Cohort", Review of Economics and Statistics, 76, 399-412.

Thomas, C. W. (2000) Home Page accessed 6 August 2000 http://web.crim.ufl/pcp/

Trumbull, W. (1989), "Estimation of the Economic Model of Crime Using Aggregate and Individual Data", Southern Economic Journal, 94, 423-39.

United States v. Bergman, United States District Court, Southern District of New York, 1976, 416 F.Supp.496.

van Dijk, F and de Waard, J. (2000), Legal Infrastructure of the Netherlands in International Perspective, Ministry of Justice, The Netherlands. (http://www.minjust.nl:8080/c actual/rapport/index.htm.

Walker, I and Sansfacon, D. (2000), Investing Wisely in Crime Prevention - International Experiences, U.S. Department of Justice, Office of Justice Programs, Washington DC.

Williams, J. Ph.D. Thesis, 1995.

Williams, J. and Sickles, R. (1999), “Turning from Crime: A Dynamic Perspective”, mimeo.

Witt, R. and Witte, A. D. (2000) "Crime, Prison and Female Labor Supply", Journal of Quantitative Criminology, 16, No. 1, March, 69-85.

Witte, A. D. (1980) "Estimating the Economic Model of Crime with Individual Data", Quarterly Journal of Economics 94:59-87. 


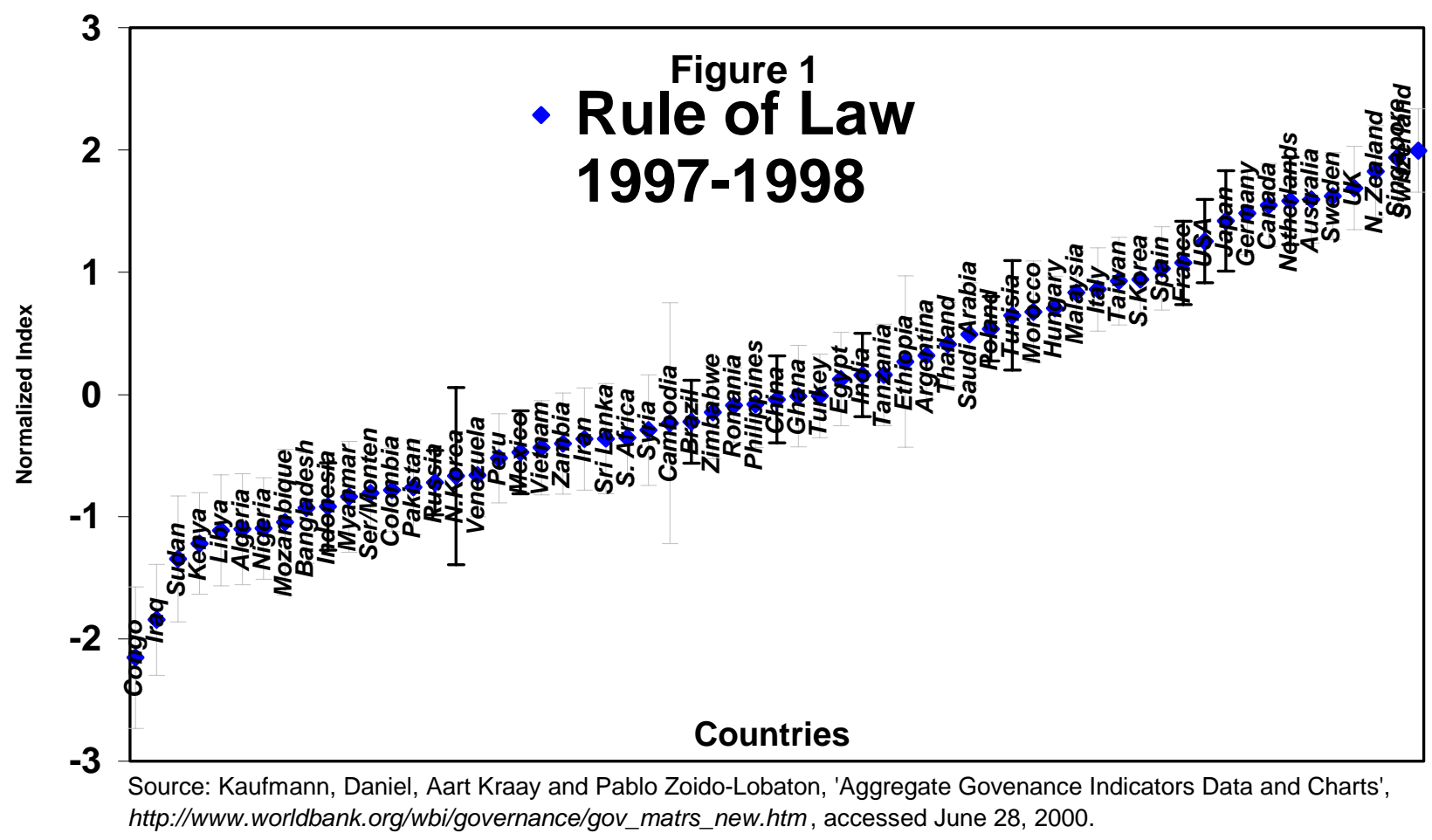




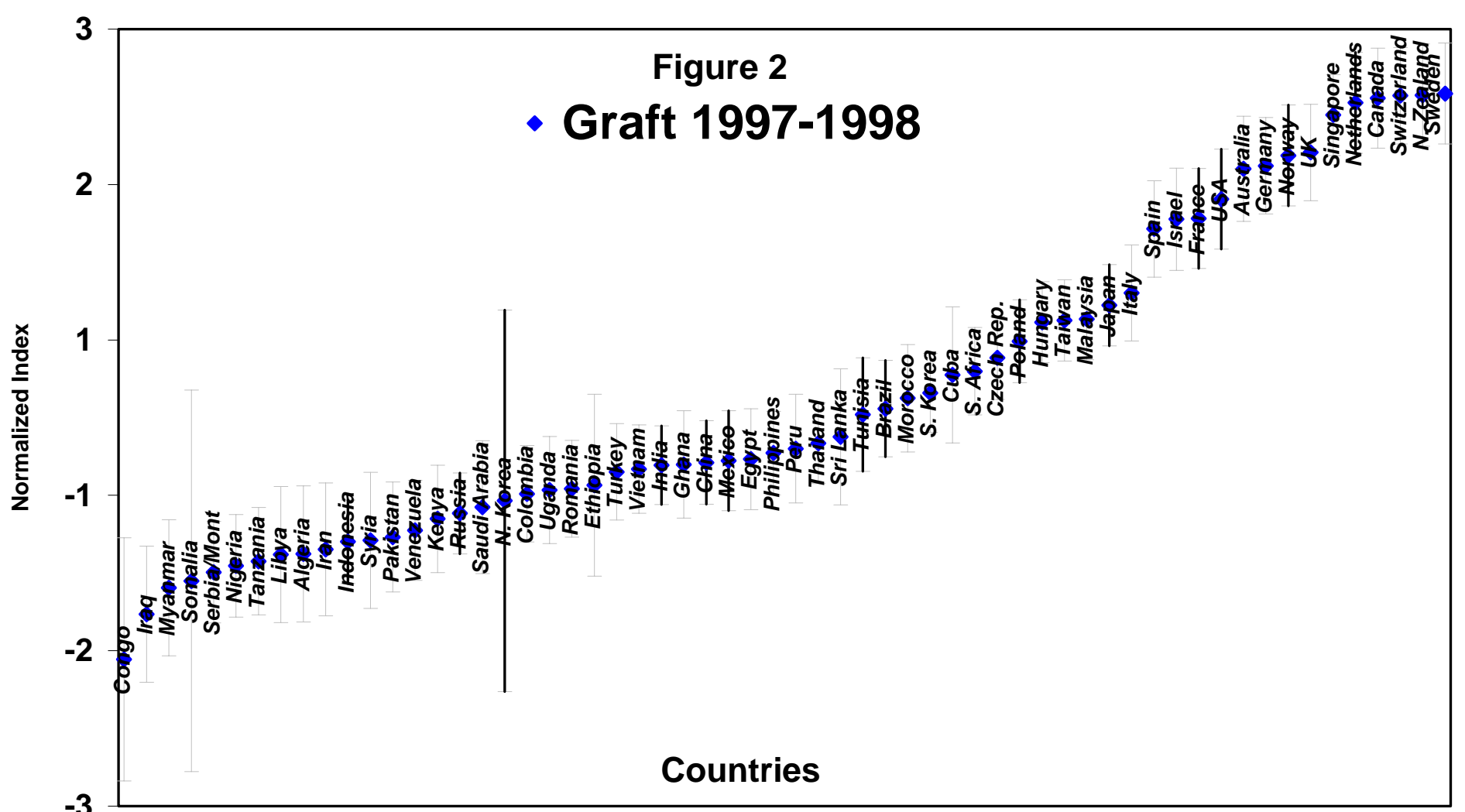

Source: Kaufmann, Daniel, Aart Kraay and Pablo Zoido-Lobaton, 'Aggregate Govenance Indicators Data and Charts', http://www.worldbank.org/wbi/governance/gov_matrs_new.htm, accessed June 28, 2000. 


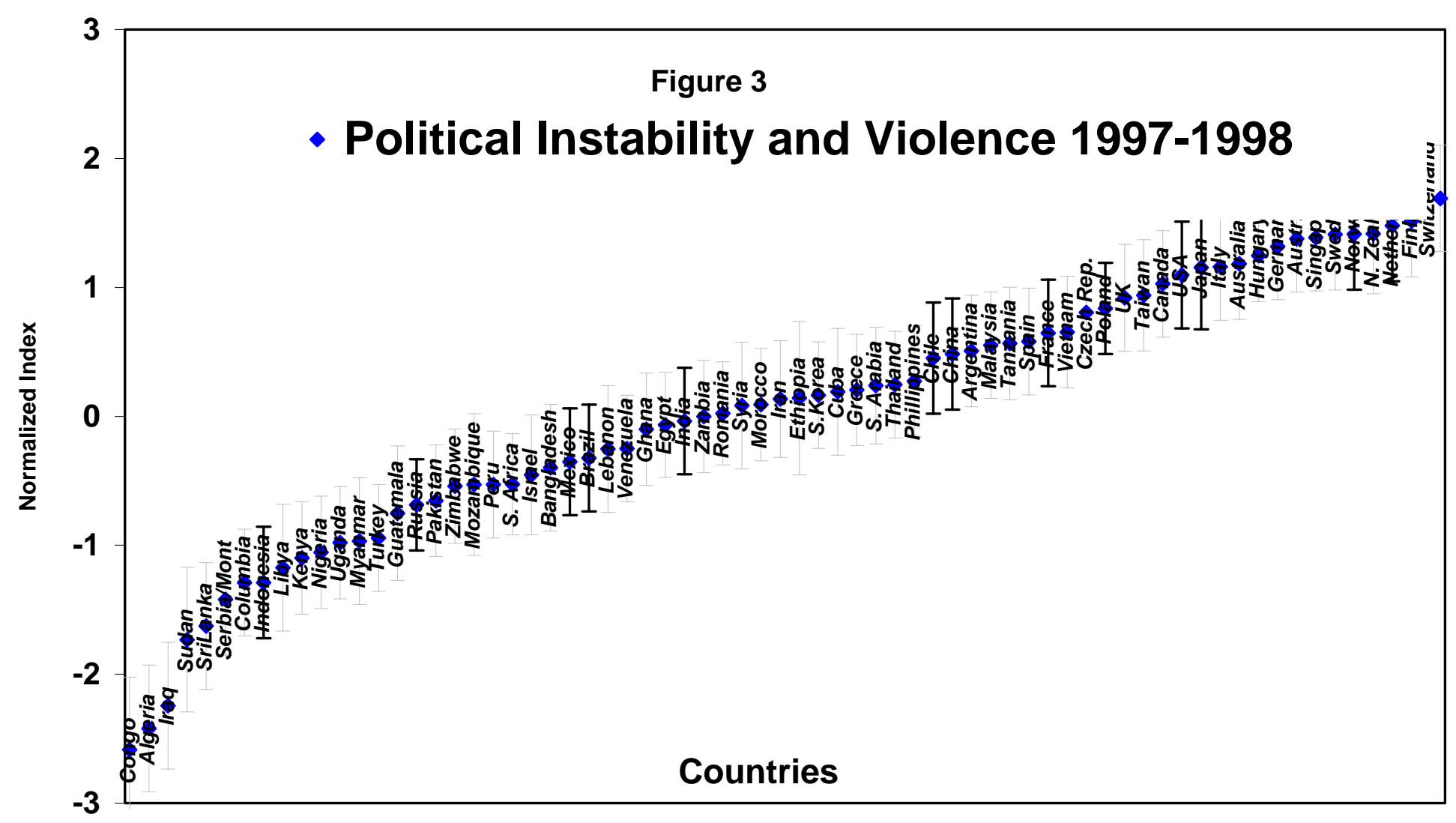

Source: Kaufmann, Daniel, Aart Kraay and Pablo Zoido-Lobaton, 'Aggregate Govenance Indicators Data and Charts', http://www.worldbank.org/wbi/governance/gov_matrs_new.htm, accessed June 28, 2000. 